Florida International University FIU Digital Commons

\title{
Entrenching African Pentecostalism in the United States of America: A Study of a Ghanaian Founded Charismatic Church in South Florida
}

Raymond K. Awadzi

Florida International University, rawad003@fiu.edu

DOI: $10.25148 /$ etd.FIDC000250

Follow this and additional works at: https:// digitalcommons.fiu.edu/etd

Part of the Christianity Commons, and the Missions and World Christianity Commons

\section{Recommended Citation}

Awadzi, Raymond K., "Entrenching African Pentecostalism in the United States of America: A Study of a Ghanaian Founded Charismatic Church in South Florida" (2016). FIU Electronic Theses and Dissertations. 2475.

https://digitalcommons.fiu.edu/etd/2475 


\section{FLORIDA INTERNATIONAL UNIVERSITY}

Miami, Florida

\section{ENTRENCHING AFRICAN PENTECOSTALISM IN THE UNITED STATES OF AMERICA: A STUDY OF A GHANAIAN FOUNDED CHARISMATIC CHURCH IN SOUTH FLORIDA}

A thesis submitted in partial fulfilment of the

requirements for the degree of

MASTER OF ARTS

in

RELIGIOUS STUDIES

by

Raymond Kwaku Awadzi

2016 
To: Dean John Stack

School of International and Public Affairs

This thesis, written by Raymond Kwaku Awadzi, and entitled Entrenching African Pentecostalism in the United States of America: A Study of a Ghanaian Founded Charismatic Church in South Florida, having been approved in respect to style and intellectual content, is referred to you for judgment.

We have read this thesis and recommend that it be approved.

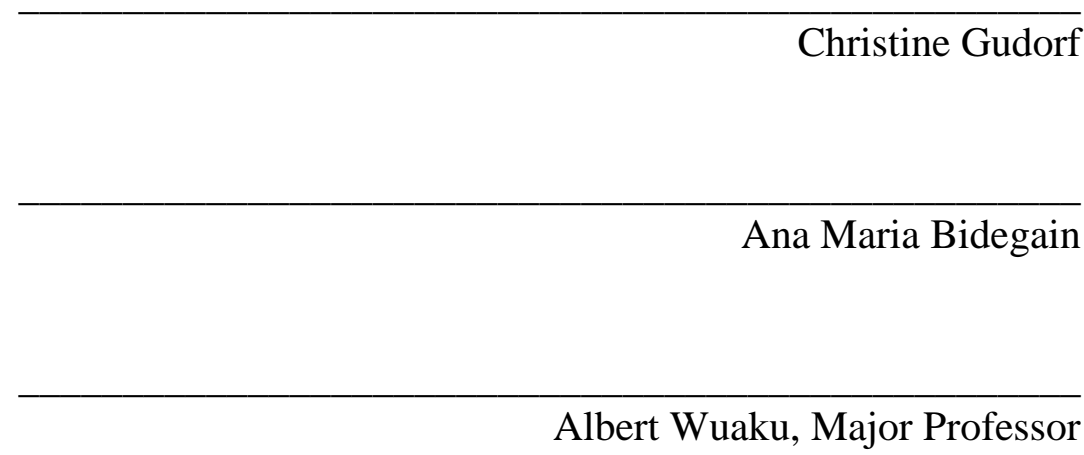

Date of Defense: March 30, 2016

The thesis of Raymond Kwaku Awadzi is approved.

Dean John Stack

School of International and Public Affairs

Andrés G. Gil

Vice President for Research and Economic Development and Dean of the University Graduate School

Florida International University, 2016 
(C) Copyright 2016 by Raymond Kwaku Awadzi

All rights reserved. 


\section{DEDICATION}

I dedicate this thesis to my parents (John K. Awadzi and Beatrice A. Duhoe), other families and friends for standing behind me in this academic journey. 


\section{ACKNOWLEDGMENT}

\section{Thanks and Glory To God Almighty}

I am grateful to my thesis committee members, Dr. Albert Wuaku, Dr. Christine Gudorf and Dr. Ana Maria Bidegain for their invaluable contributions in the form of suggestions, guidance and support in diverse way for the successful completion of this research. I am very thankful to Dr. Wuaku, my Major supervisor, for invoking this research interest in me and shaping it to meeting innovative academic standards. I really appreciate his sacrifices for the nights we had talk and chat on WhatsApp, all in the interest of meeting deadlines with an excellent work. Dr. Wuaku (Uncle), nu mexlea afi o, Mawu nayra wò. My special thanks go to Dr. Gudorf for her constructive criticism that broadened my knowledge on the topic as well as the editorial work that put my discussion into right perspectives. I cannot but say God bless you exceedingly for the love and kindness Dr. and Mr. Gudorf shown by giving me their apartment for one year in my study at FIU and the many other supports they forbade me not to tell anybody. Thanks and blessings to Dr. Bidegain for providing me with the expertise and continuous motherly encouragement throughout my studies.

I am also grateful to all my professors at the Religious Studies Department especially, Dr. Oren Stier for his constant reminders and to Dr. Erik Larson for his words of inspiration that kept me going. I acknowledge with gratitude the contributions of my graduate colleagues in respect of the many discussions regarding our research and the constant reminders when deadlines approach. Thanks to Maurisa who ushered me into the FIU community; and thanks to Isis (Aku) who drove me to the research field at Miami Gardens on many occasions. My heartfelt appreciations go to Dr. Edmund Abaka 
of University of Miami and his wife, Alberta Acquah for the parental care they gave me from my first day at Miami till the end of my studies. They took upon themselves all my pains and provided me with everything I needed to survive in Miami. Similar appreciation goes to Rev. Dr. Elom Dovlo of Mount Crest University, Ghana, Rev. Y. K. Ahiabu and his foundation (the Living Flame Media Ministry) for their immense support and contributions to my academic journey.

I am indebted to the Head Pastor Rev. Dr. Emmanuel Eyim-Danquah for introducing me to his church and for allowing me to use the church as a case study. I am so grateful for the times he had to wait for me at the church premises in order to grant me interview. To the Eyim-Danquah family and other members of the Christian Restoration Ministries International, I wish them God's blessing for the warm reception they gave me each time I visit the church and also for granting me interviews out of their busy schedules.

Finally, I have a special thanks to my fiancée Bubune, for her endurance, encouragements and many other supports including reading through my drafts. Chercheer, may God bless you. Thanks to Jonathan Sagba, Charles Fiador, Pastor Anthony and Mrs. Virginia Manuel, Madam Asiwome Efa, Mr. Emmanuel Kamassah, my siblings and other members of the Awadzi, Kamassah, and Nyavlo families for their prayers. "You are, therefore, I am.” Mawu nayra mi kata. 
ABSTRACT OF THE THESIS

ENTRENCHING AFRICAN PENTECOSTALISM IN THE UNITED STATES OF

AMERICA: A STUDY OF A GHANAIAN FOUNDED CHARISMATIC CHURCH IN

SOUTH FLORIDA

by

Raymond Kwaku Awadzi

Florida International University, 2016

Miami, Florida

Professor Albert Wuaku, Major Professor

For the past three decades, there has been a rapid growth of African Pentecostal Christianity on America’s Christian religious scene. In general, researchers in Christian mission studies have concluded that the flow of Christian religious currents from Africa and other Third World countries to the West is something of a Christian mission in reverse process. Using agency and invention of tradition as the theoretical leads, this study explores the roles lay immigrants played in the rooting of the Christian Restoration Ministries International (CRMI), a Ghanaian founded charismatic church, in Miami, as a case study of how African Pentecostal churches originate in America. The study also shows how the Christian Restoration Ministries International (CRMI), practices an invented version of Ghanaian Pentecostalism. The study is field-work based. It concludes that the so called reverse mission thrives on the crucial roles of lay African migrant worshippers and their inventiveness. 
TABLE OF CONTENTS

CHAPTERS

PAGES

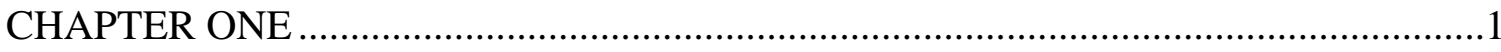

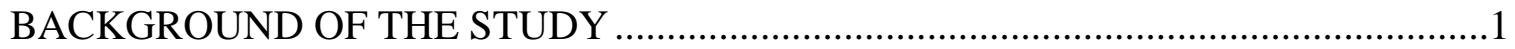

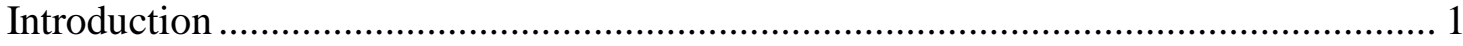

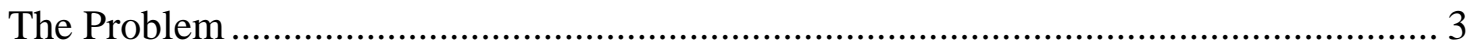

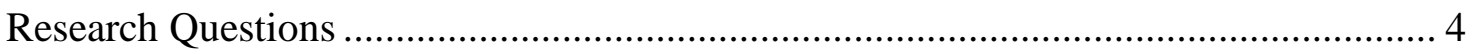

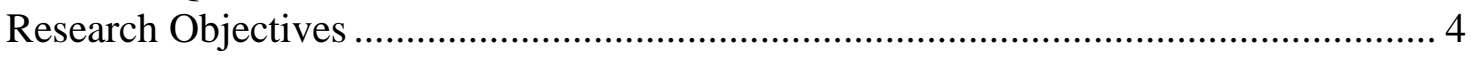

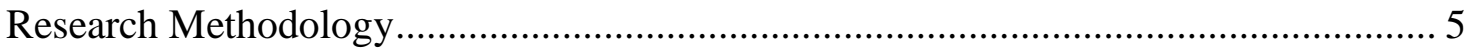

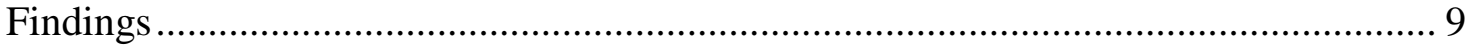

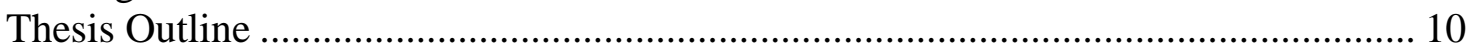

Relevance of the Study............................................................................................ 10

CHAPTER TWO …………………………………………………………………..12

CONTEXTUALISING IMMIGRATION AND AFRICAN PENTECOSTALISM

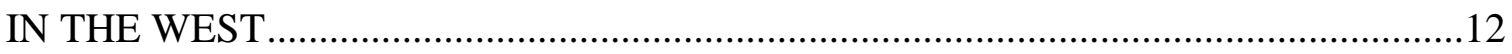

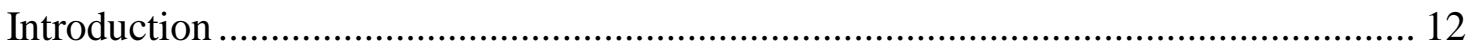

Ghanaian Charismatic (Neo-Pentecostal) Churches …………………………............. 13

Ghanaian Charismatic Churches: Beliefs and Practices ............................................ 19

Ghanaian Charismatic Churches and Global Mission............................................... 21

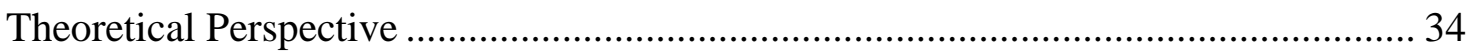

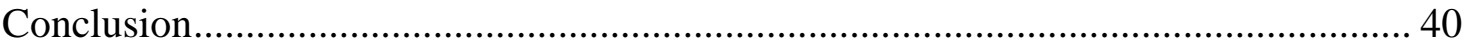

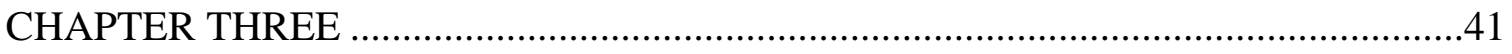

HISTORY OF CHRISTIAN RESTORATION MINISTRIES INTERNATIONAL IN

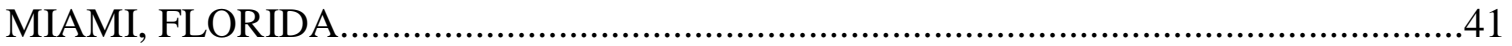

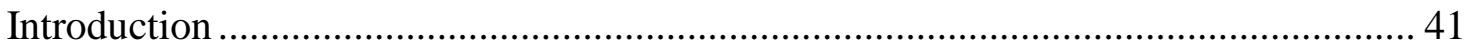

The Church as an Institution .................................................................................. 41

The Story of the Church's Origins ............................................................................. 44

Christian Restoration Ministries International (CRMI) ............................................... 46

Rev. Emmanuel Eyim-Danquah and His Family ............................................................ 47

Founding Christian Restoration Ministries International (CRMI)............................. 51

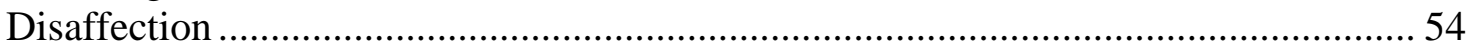

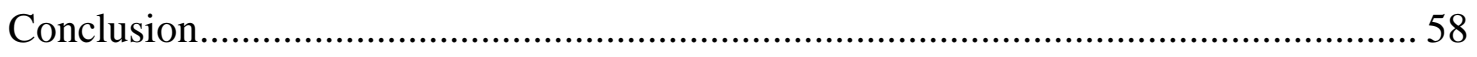

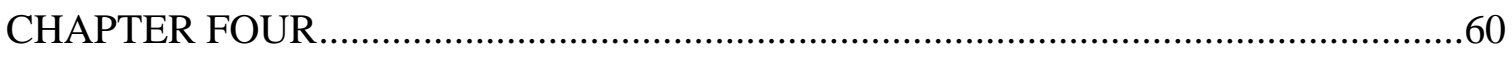

THE CHRISTIAN RESTORATION MINISTRIES INTERNATIONAL CHURCH

AS AN INVENTED GHANAIAN PENTECOSTALISM ...............................................60

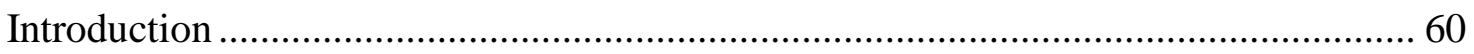

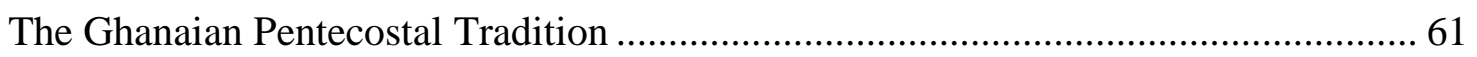

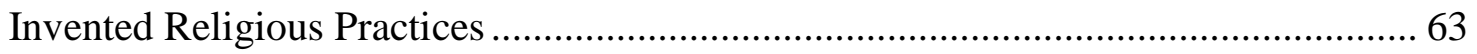

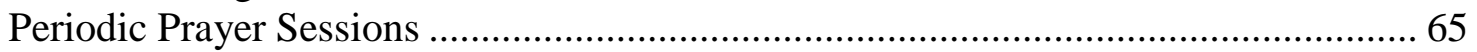

Intercessory Prayers/Prayer Meeting ......................................................................... 68

Prophetic Prayer Conference........................................................................................ 70 
Impact Service and Solution Hour (Healing and Deliverance Program) .................... 72

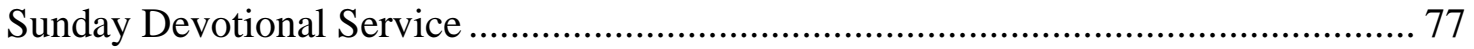

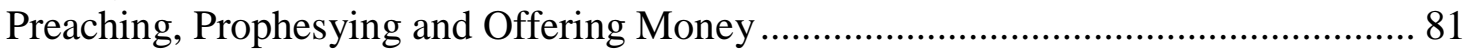

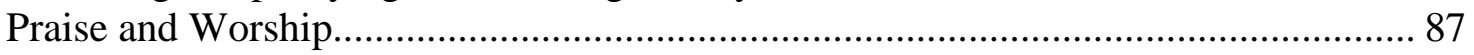

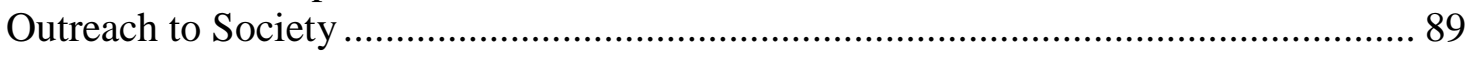

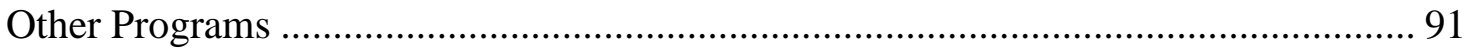

Evangelization and Recruitment Practices ........................................................ 92

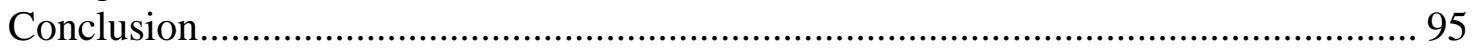

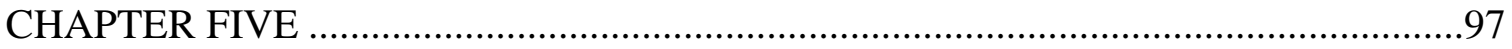

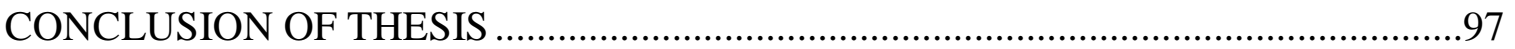

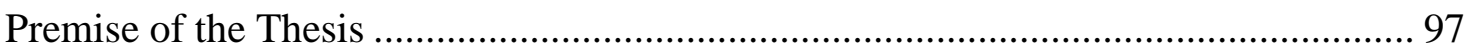

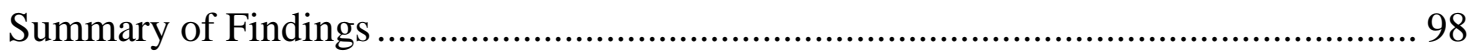

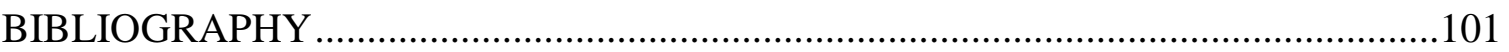

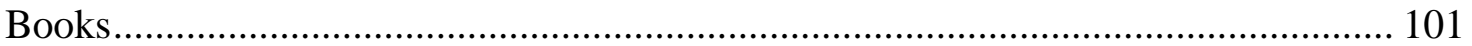




\section{CHAPTER ONE \\ BACKGROUND OF THE STUDY}

\section{Introduction}

For the last two decades or more, the United States of America has been witnessing the proliferation of African immigrants in many parts of the country. These migrants, many of whom have just escaped dire circumstances in their homes, suddenly find themselves in exile, detached from their communities' languages and socio-cultural milieu. In the 2012 United States of America (USA) census report, it was estimated that more than one million six hundred thousand African migrants reside in the country. ${ }^{1}$ The influx of African immigrants into the United States and their subsequent settlement either as naturalized citizens, legal aliens or non-legal aliens, is changing the socio-cultural and religious landscape of the country. This immigration phenomenon has led to the rise of African churches in America, adding new players to the already pluralistic religious landscape of the United States of America and increasing the religious diversity in the USA. $^{2}$ Furthermore as their numbers in the USA grow, African migrants are making a significant social and cultural impact, especially through the proliferation of Pentecostal religious communities. These churches are common in gateway cities such as New York,

\footnotetext{
${ }^{1}$ Christine P. Gambino, Edward N. Trevelyan, and John Thomas Fitzwater, "The Foreign-Born Population from Africa: 2008-2012",

http://www.census.gov/content/dam/Census/library/publications/2014/acs/acsbr12-16.pdf Issued October 2014, Accessed Sep. 25, 2015.

${ }^{2}$ Akintunde E. Akinade, "Non-Western Christianity in Non-Western World: African Immigrant Churches in the Diaspora," in Jacob K. Olupuna and Regina Gemignani (eds.), African Migrant Religion in America (New York University Press, 2007), 89.
} 
Washington, DC, Chicago, Atlanta, Houston, Miami and Los Angeles, where the most rapid spread of African immigrant communities is occurring. ${ }^{3}$

The sudden rise of African churches in the West is not unique to the USA. There is a burgeoning literature on the European and even Australian portion of this experience. In the emerging literature, authors have dubbed the experience "the reverse mission experience.” The idea here is that Africans who were previous recipients of the gospel message from the Western Christian mission enterprise are now evangelizing the former heartlands of Christianity. ${ }^{4}$ In other words, the historical trajectory of "missionizing," which was from the West to Africa, has been reversed. Reinforcing the notion of a reverse mission are the ways in which African home churches with extensions in the diaspora define their mission in terms of responses to the need for the evangelization of Europeans and Americans, who, they claim, have departed from the faith. ${ }^{5}$

A cursory observation of African Pentecostal churches in America demonstrates that the reverse mission paradigm overlooks the contribution of African migrant worshippers, some lay, others, already in the Christian ministry, in the rooting of African Christianity in the USA. Often, it is these migrants who initiate prayer cells in their homes to meet their spiritual needs in the diaspora. Churches from the African homeland only come in to seize these initiatives, often at the invitation of the migrant founders. The

\footnotetext{
${ }^{3}$ Alex Stepick, Terry Rey and Sarah J. Mahler, Churches and Charity in the Immigrant City: Religion, Immigration and Civil Engagement (New Brunswick: Rutgers University Press, 2009), 4-8.

${ }^{4}$ J. K. Asamoah-Gyadu, “An African Pentecostal in Eastern Europe: The Church of the 'Embassy of God' in Ukraine,” Pneuma: The Journal of the Society for Pentecostal Studies, 27 (2005), 297.

${ }^{5}$ Afe Adogame, Roswith Gerloff and Klaus Hock, Christianity in Africa and the African Diaspora: The Appropriation of a Scattered Heritage, (New York: Continuum International Publishing Group, 2008 ), 3.
} 
reverse mission notion creates the impression that all the African Pentecostal churches abroad originated as products of organized proselytizing activities of African churches from the homeland. Also, the literature does not say much about how African Pentecostal traditions, which are heavily inflected with indigenous African religious beliefs and practices, negotiate their worship cultures as they adapt to the ethos of the American or European religious landscapes in which they operate. How do these churches become American? What innovations do they make? In what ways do they retain their "Africaness" in America? This study has attempted to explore these questions in the context of the history and worship tradition of the Christian Restoration Ministries International, a Ghanaian-founded Neo-Pentecostal or Charismatic Church in North Miami, Florida.

\section{The Problem}

The Christian Restoration Ministries International (CRMI), the case for this research, is a Ghanaian-founded Charismatic church in North Miami, Florida. The church is 12 years old. After eight years of service in Christian ministry in Ghana, the founder and Presiding Bishop, Dr. Emmanuel Eyim-Danquah migrated to the USA. The church primarily started with Ghanaian immigrants in the founder's home as a prayer group. When the cell's membership grew to about forty (40) regular attendants, it became necessary for the group to relocate to a permanent church building more conducive to their purposes; it is currently located at $19255 \mathrm{NE} 3^{\text {rd }}$ Ave. North Miami, Florida. The CRMI currently has about one hundred (100) members and holds church services twice every Sunday. The church which was founded with a few Ghanaians now has a membership constituted also 
of different ethnicities from the Caribbean, Latin America, USA and India. The diversity of the current membership has necessitated some form of adjustment in the Ghanaian Pentecostal culture to meet the needs of members with socio-cultural and religious worldviews other than Ghanaian. Also the church now has links with preachers from Ghana and other African countries, who use it as a platform to spread their influence in the USA. Given these features, the Christian Restoration Ministries International (CRMI) offers a good context for the exploration of the following questions.

\section{Research Questions}

- What is the role of individual migrant Pentecostal worshippers of CRMI in the reverse mission?

- How is this African Pentecostal Church, which is heavily embedded in the African religious worldview, Americanizing? In other words, how is it adapting to the religious ethos of the USA?

- How does it speak to the needs of its non- Ghanaian members?

- What new practices is it adopting and to what extent is the church maintaining its Ghanaian identity?

\section{Research Objectives}

- The objective of the research is to investigate, document and analyze the history and culture of this South Floridian African Neo-Pentecostal Church with a focus on the role of the migrant originators in its beginning, the creative innovations the 
church is making to speak to the needs of members in the USA, and the church's contribution to the reverse mission.

\section{Research Methodology}

The study involved the use of religious ethnography as the main methodological approach. This entailed participant observation of the activities of CRMI at its locus in North Miami and other locations it uses for worship. I also interviewed the founders and members of the church to learn about its history, their experiences, the innovations the church is making, which areas of the culture are involved, and why. In addition, I explored secondary and primary sources of information that shed light on the church and its experiences.

I therefore explored primary methods of data collection extensively to achieve the objectives of this research. These include critically observing activities of the church and the immediate environment in which religious activities regularly take place. To achieve this, I relied on participant observation as one primary source for data collection. Olav Dahlin observes that for a researcher "to be able to apprehend the insider view, it is important to interact and take an active role in the everyday life of the people studied, that is 'to be there' as much as possible." ${ }^{6}$ In order to obtain details of routine religious activities, I actively participated in the various programs organized by the church. I also observed Sunday church services of CRMI at its locus in North Miami and other locations it uses for worship. I endeavored to join in activities such as regular online

${ }^{6}$ Olov Dahlin, Zvinorwadza: Being a Patient in the Religious and Medical Plurality of the Mberengwa District, Zimbabwe (Frankfurt am Main: Peter Lang, 2002), 22. 
worship and prayer sessions, dedication of children, evangelism activities, homes of members and other public spaces where religious activities were held.

I also used interviews and focus group discussions in my data collection processes. First, I used unstructured guided interview to gather information from the individual members of the church concerning their views on the church and its activities. The unstructured guided interview has been used to elicit information from targeted individuals who represent different identifiable sub-groups that constitute the church membership. These include prayer warriors, praise and worship team, elders and the youth groups. The purpose is to ensure that information gathered becomes relatively representative of general membership of the church. Furthermore, I engaged some members of the church in focus group discussion. This primary source of data collection involves engaging carefully selected personalities at the research field in a group discussion on specific issues under investigation. This method is meant to help gain a broader perspective of issues being studied, in that the method brings a lot of views on board which otherwise may not be revealed by one informant. The main purpose is to gather information about their backgrounds and how they are linked with the history of the church, their experiences and how they inform innovations in the church as well as why those innovations became necessary in the history of the church. In all, I engaged about forty-five (45) respondents (current members and those who defected) in interviews and focus group discussions concerning their opinion on the founding of CRMI and its activities. 
During interviews and group discussions, I recorded information that informants gave with the aid of an electronic voice recorder as well as taking short notes. I did these through overt and covert approaches to ensure that information gathered truly reflects the research field. The use of multiple data recording approaches is informed by the need to keep detailed information gathered on the research field as well as to prevent relevant clues from eluding my attention due to my participation in the group’s activities. They are also meant to help capture and provide concrete description of relevant aspects of religious proceedings and how they unfold in the most natural language. ${ }^{7}$ This multidimensional approach to the study has facilitated accuracy and credibility of data for discussion, an approach that Vincent A. Anfara, et, al. refer to as the triangulation method. The method has also helped to substantiate data from different sources to ensure the authenticity of the information elicited. ${ }^{8}$

I employed the qualitative data analysis approach under which the ethnographic method falls in order to evaluate data gathered during the field work. This is "a form of social inquiry that tends to adopt flexible and data-driven research design, to use relatively unstructured data, to emphasize the essential role of subjectivity in the research process, to study a small number of naturally occurring cases in detail, and to use verbal rather than statistical forms of analysis." ${ }^{9}$ It relies on the quality of the information based

\footnotetext{
${ }^{7}$ Hammersley, Martyn, What is Qualitative Research? (New York: Bloomsbury Publishing Plc, 2013), 12.

${ }^{8}$ Vincent A. Anfara, et al. "Qualitative Analysis on Stage: Making the Research Process More Public," http://www.researchgate.net/publication/228779917 [Accessed August 5, 2015].

${ }^{9}$ Hammersley, What is Qualitative Research? 12.
} 
on its relevance to the subjects being studied rather than reliance on the quantity of responses to a particular issue. That is, instead of drawing from a large representative sample, the researcher seeks to acquire in-depth and intimate information from a relatively smaller group of persons. ${ }^{10}$ As part of the qualitative method I adopted both descriptive and interpretative approaches.

By descriptive approach, I mean that I offered accurate accounts of events I considered relevant data for discussion in the light of the main themes of this study. In addition, I used the interpretative approach to data evaluation and discussion. This has helped in gaining meanings and the relative significance of the various activities of the church. In doing so I sought to understand the participants and their various religious activities from their own points of view (insider perspective). I adopted these approaches and I followed the lead of other scholars. For example, Hammersley and Atkinson contend that “in order to understand people's behavior we must use an approach that gives us access to the meanings that guide their behavior. As participant observers we can learn the culture or subculture of the people we are studying. We can come to interpret the world more or less in the same way that they do." 11 Truzzi refers to this approach as Verstehen; arguably borrowing a term from Weber. ${ }^{12}$ Clifford Geertz's refers to the

\footnotetext{
${ }^{10}$ B. M. Wildemuth, "Understanding and Evaluating Qualitative Research," Journal of Marriage and the Family63 (1995), p. 881.

${ }^{11}$ Martyn Hammersley and Paul Atkinson, Ethnography Principles in Practice (Third edition) (New York: Routledge Taylor \& Francis Group, 2007), 8.

${ }^{12}$ M. Truzzi (ed.), Verstehen: Subjective Understanding in the Social Sciences, Reading (MA: AddisonWesley, 1974).
} 
approach as "thick description."13 My goal was to understand and explain the meanings of the church's beliefs and practices as an example of an African Pentecostal expression in America.

\section{Findings}

I discovered that the formation of CRMI was born out of the initiatives of ordinary immigrants who came to America in order to better their living conditions. This church is an illustration of the significant roles ordinary immigrants play in the rise of African Pentecostal Christianity in America and other parts of the West. From my field research, it was evident that migration of Africans to the West is one major factor that is contributing to the rise of African Pentecostal Churches in America and other Western countries. Also, it became evident from my studies that the Ghanaian immigrants had to reinvent aspects of African Pentecostal traditions in rooting their Pentecostal beliefs and practices in the USA. As a result of this invention process, the church appears American but at the same time African in its approaches to religious activities. Finally, this research has discovered that the African Pentecostal Churches have succeeded in the reverse mission processes owing to the ability to contextualize their Christian religious ethos to suit changing socio-cultural settings.

\footnotetext{
${ }^{13}$ Daniel L. Pals, Seven Theories of Religion (New York: Oxford University Press, 2006), 267. See also Clifford Geertz, Thick Description: Toward an Interpretive Theory of Culture,” In The Interpretation of Cultures: Selected Essays (New York: Basic Books, 1973), 3-30.
} 


\section{Thesis Outline}

The research has been organized under five chapters. Chapter one offers a general background to the study. It includes an introduction, problem statement, objectives, and the methods of data collection used in the study. Chapter two develops the various concepts and shows how they help us to understand the data theoretically. I also offer a review of relevant literature in the second chapter of the research. Chapter three introduces readers to the community, its location, ethnographic characteristics and membership. It narrates the history of CRMI and indicates the roles played by ordinary Ghanaian immigrants in the formation of the church. The fourth chapter concentrates on the beliefs, practices and ritual systems of the CRMI, demonstrating the agency of the Ghanaian migrants in the creation and evolution of the unique identity of the church as African and at the same time American Pentecostal Church. The fourth chapter also demonstrate the invention processes that members of CRMI employed to ensure the rooting of the church in South Florida. In the fifth chapter, I concluded the study by tying together the strands of my arguments and summarizing my major findings.

\section{Relevance of the Study}

This research is significant in its contribution to church history and Christian mission, on the one hand, and Pentecostalism on the other hand. Many scholars have pointed out the emerging religious phenomenon about the spread of African Christianity to the West as Christianity is experiencing decline in the West. The transnational outlook of African Pentecostalism and motivation to spread the gospel to Europe and North America requires some form of critical examination. According to Lamine Saneh, "religion is now 
in the twilight of its Western phase and at the beginning of its formative non-Western impact. Christianity has not ceased to be a Western religion but its future as a world religion is now being formed at the hands and in the minds of its non-Western adherents." 14

Also, David D. Daniels asserts that despite their major impact in the United States of America, migrant churches appear to be invisible to scholars, leading to less research on them. ${ }^{15}$ Using Christian Restoration Ministries International as a case, this research examines how non-Western adherents (in Ghanaian Charismatic churches) are shaping Christian religious expression in North America. This study is also significant in evaluating how the Western world is responding to the growing phenomenon of reverse mission. Finally, this research is very important in assessing the extent to which contemporary missionary activities of African Charismatic Christianity in the global sphere constitute what most scholars have labeled "reverse mission," "reverse flow” or "remissionization.” Highlighting the place of African migrants in the rooting of African Pentecostalism in the USA has contributed to better understandings of what the reverse mission really entails.

\footnotetext{
${ }^{14}$ Lamine Saneh, "Introducing the Oxford Series," in Anders Heaton Anderson, To the Ends of the Earth: Pentecostalism and the Transformation of World Christianity (Oxford University Press, 2013), xiv.

${ }^{15}$ David D. Daniels, "African Migrant Churches in the United State and the Study of Black Church History,” in Jacob K. Olupuna and Regina Gemignani (eds.), African Migrant Religion in America (New York University Press, 2007), 48.
} 


\section{CHAPTER TWO}

CONTEXTUALIZING IMMIGRATION AND AFRICAN PENTECOSTALISM IN

\section{THE WEST}

\section{Introduction}

The origin of African Pentecostalisms and their subsequent spread to the Western world is the subject of an emerging body of scholarly research. Most of the studies on African Pentecostal churches elaborate their establishment in Africa, their beliefs and practices, their impact on the immediate and the distant socio-cultural, economic and political climate within which they operate, and the global posture they have taken in their mission activities.

Generally, African Pentecostal traditions are distinctive African variants of Pentecostal Christianity. In a sense they represent a unique African contribution to world Christianity. Earlier studies focusing on Christian mission activities beyond the continental borders of the churches have acknowledged the presence of African Pentecostal churches in many parts of the world, including Europe and North America. Previously, the research contended that African churches in the West only served the religious and socio-economic needs of African immigrants. However, recent scholarly evaluation and observations have shown that African Pentecostal churches have expanded their religious activities to embrace people other than African immigrants in the 
West. ${ }^{16}$ This and many other factors have led to the characterization of African Pentecostal mission processes in the West as a form of reverse missionizing.

I divide this chapter into two parts. In the first part, I review a selection of relevant literature on African Pentecostal Christian missions in the West. The purpose is to identify the relevant themes in the emerging body of research I can build on, and the gaps I need to fill using data gathered from field work done in Christian Restoration Ministries International (CRMI); a Ghanaian founded Charismatic church in Miami in South Florida. In the second part, I identify and discuss some theories, concepts and terms I considered relevant in understanding the CRMI and its religious activities in Miami, theoretically. The theories and concepts have created the framework within which I situated the discussions of the field data I gathered on this Christian community.

\section{Ghanaian Charismatic (Neo-Pentecostal) Churches}

There is a vast body of literature on Pentecostalism exploring the subject from different disciplinary perspectives. The diversity of both scholarly and non-scholarly works on Pentecostal Christianity is a reflection of the multiplicity of its expressions. These traditions operate in different socio-cultural settings and have impacted different facets of people's endeavors, especially since start of the twentieth century. However, for the purpose of this research I have focused attention on literature I consider relevant to the understanding of Ghanaian Pentecostal Christian religious expressions in Ghana and abroad.

\footnotetext{
${ }^{16}$ Afe Adogame, The African Christian Diaspora: New Currents and Emerging Trends in World Christianity (New York: Bloomsbury, 2013), 149.
} 
In his Introduction to Pentecostalism: Global Charismatic Christianity, Allan Anderson traces the contemporary Pentecostal religious expression in its global manifestations to the New Testament early Christian experience, through the Middle Ages, to the present era, that is, the twenty-first century, occasioned by a diversity of Pentecostal and Charismatic Christian religious practices. Anderson's approach helps us to understand the historical processes that have shaped this strand of Christianity into the contemporary independent Pentecostal Christian religious expression known and identified as Neo-Pentecostal churches or Charismatic churches. The book also sheds light on how the Charismatic Christian religious movements have spread across the globe including Ghana, which is the source of CRMI's African Pentecostal heritage. ${ }^{17}$ Anderson identifies some defining elements of Pentecostalism that explain its global expansion. Among these themes are the centrality of referencing the in-working of the Holy Spirit in their religious activities, notion of the "full gospel," contextualization as their unique approach to mission, their education system, and ecumenism. ${ }^{18}$ These features are also identifiable with Ghanaian Neo-Pentecostal Churches, one of which is the context in which the founder of CRMI nurtured his religiosity. It is important to state that the term "Pentecostals" and "Charismatics" (Neo-Pentecostal) are used interchangeably to refer to those churches that emphasize the active presence of the Holy

\footnotetext{
${ }^{17}$ Allan Anderson, Introduction to Pentecostalism: Global Charismatic Christianity (Cambridge: Cambridge University Press, 2004), 19, and 115-122.

${ }^{18}$ Anderson, Introduction to Pentecostalism, 206-208.
} 
Spirit in their normal Christian religious expression. ${ }^{19}$ In the case of Ghana and other Sub-Saharan African countries, "Charismatic" is used in reference to independent Pentecostal movements who heavily drew religious inspiration from North American neo-Pentecostal movements. The CRMI can therefore be identified as a Charismatic Church.

Anderson's work offers us a very much needed historical understanding of Pentecostal traditions such as the CRMI, which this study is about. However, missing, or only cursorily treated in his work, are detailed accounts of the agents involved in the global circulation of these traditions, the processes by which the charismatic movements are establishing roots in different parts of the world, and how they are adapting to the religious ethos of these new homes. Similarly, in her work, The Charismatic Movement, Margaret Poloma also shed light on the historical background of Charismatic churches, with a particular focus on the charismatic movements in United States of America, the setting of the present study. In her studies, Poloma identifies the role of some parachurch movements in the establishment of Charismatic churches in America. Among these church movements are the Full Gospel Business Men Fellowship International (FGBMFI), Catholic Charismatic Renewal, and other renewal movements from Protestant denominations. ${ }^{20}$ There is a striking parallel between the roles para-church

\footnotetext{
${ }^{19}$ Kwabena J. Asamoah-Gyadu, African Charismatics: Current Developments within Independent Indigenous Pentecostalism in Ghana (Leiden: Koninklijke Brill NV, 2005), 1 and 16. See also, Anderson, Introduction to Pentecostalism, 155-156.

${ }^{20}$ Margaret Poloma, The Charismatic Movement: Is There a New Pentecost? (Boston: Twayne Publishers, 1982), 13-19.
} 
movements play in the formation of some Charismatic churches in Ghana. ${ }^{21}$ What is significant about Poloma's studies is her assertion about the rapidly growing population of black charismatic churches at both denominational and membership levels. Although Poloma did not identify the factors contributing to the rise of these churches (of which CRMI is a member), her work provides insight into the rapid spread of black Pentecostalism in the USA; and the need to research the respective contributing factors.

Asamoah-Gyadu's African Charismatics uses Ghanaian Neo-Pentecostal or Charismatic Churches to explicate some of their beliefs and practices as examples of distinctive features of African Charismatic churches. Using a thematic approach, Asamoah-Gyadu discusses the features of the Charismatic religious praxis in Ghana. Among the defining features of Ghanaian charismatic churches that Asamaoh-Gyadu identifies are prophetic phenomena, democratization, and expression of charismata, the notion of salvation as source of transformation, healing and deliverance, the prosperity gospel, and expressions of African spirituality. Asamoah-Gyadu further explains that despite the strong African flavor of their beliefs and practices, Ghanaian Charismatic churches show a predilection for the adoption of American Evangelistic formats, especially the style of American media evangelists. This is because:

In Ghanaians eyes, North America, with its technological superiority and material abundance, epitomises modernity. For a religion that seeks to be modern and preaches material abundance as a sign of right standing with God, as the CMs do, what comes from America is a great source of enhancement and inspiration. The core of the message of Ghanaian CMs is not American as such.

${ }^{21}$ Cephas N. Omenyo, Pentecost Outside Pentecostalism: A Study of the Development of Charismatic Renewal in the Mainline Churches in Ghana (Zoetermeer: Boekencentrum Publishing House, 2006), 38,104 \&115. 
It is the way it is expressed that betrays a predilection for the style of American media evangelists. ${ }^{22}$

Asamoah-Gyadu's observations underscore the impact of American culture on African communities in general. This impact goes beyond religion. It is felt in every dimension of the experiences of African countries. While Asamoah-Gyadu may be right in his assessment, I argue that the desire of Ghanaian Charismatics to Americanize is also in keeping with their globalizing agenda. Because of their preoccupation with expansion, and with making America and other nations of the West destinations for their missionary activities, they see the need to design religious activities to suit expectations of these prospective mission zones. Asamoah-Gyadu observation also implies that Ghanaian Christians who migrate to the USA are already accustomed to some American ways of “doing” religion. We will see how this Ghanaian familiarity with the American religious ethos, and prior existing contacts with an American Evangelist in South Florida, were important factors in the origins of the CRMI.

In his book African Christianity: Its Public Role, Paul Gifford explores the rise of Africa's new forms of Pentecostalism and their roles in the political and economic developments of respective African countries. Gifford attributes Charismatic Churches’ formation in Africa to the socio-economic and political situation that prevailed during their period of establishment. His discussion underscores the significant role African Charismatic churches play, especially in the economic and political development of their respective countries. According to Gifford, the charismatic churches contribute to economic and political development through their constant criticizing of public policy.

\footnotetext{
${ }^{22}$ Asamoah-Gyadu, African Charismatics, 99.
} 
Their various Christian religious initiatives also serve as avenues for job creation. This is evident in the numerous jobs the churches are providing for skilled but unemployed youth in their communities. ${ }^{23}$ The political and economic argument for the rise of Charismatic churches also featured strongly when Paul Gifford turned his attention to the Ghanaian case in his Ghana's New Christianity. In this volume, he identified some of the main Charismatic churches in Ghana, their major religious activities, and their engagement with economic and political challenges, as well as their prospects in Ghanaian communities. Gifford's research on Africa and Ghana in particular helps us in our exploration of how and why the Restoration Ministries International was established. The economic and political upheavals that confronted Ghanaian societies in the last quarter of the $20^{\text {th }}$ century appear to be one major contributing factor to the rise and rapid growth of Ghana's Charismatic Churches. ${ }^{24}$

These very factors account for the migration of many members of these churches to Europe and the USA in search of greener pastures. As people of deep religious faith, these migrants might be expected to continue practicing their religious traditions wherever they migrate to, especially if they encounter similar hardships in their new destinations. This study will show how a small group of Ghanaian Christian migrants initiated a worshipping cell in Miami in an effort to perpetuate the Charismatic religious practices they had left behind in Ghana. This cell would blossom over the years to become the CRMI. This study also uncovers the extent to which similar socio-economic

\footnotetext{
${ }^{23}$ Paul Gifford, Ghana's New Christianity: Pentecostalism in a Globalizing Economy (Indianapolis: Indiana University Press, 2004), 88-91.

${ }^{24}$ Gifford, Ghana’s New Christianity, 19.
} 
and political factors in the USA pushed Ghanaian lay immigrants to establish the CRMI in Miami, Florida.

\section{Ghanaian Charismatic Churches: Beliefs and Practices}

In his An Introduction to Pentecostalism, Allan Anderson identified the salient religious beliefs and practices that define Pentecostal and Charismatic churches in general. Among these are the belief in the baptism of the Holy Spirit, and the belief that, as people accept the gospel, their conversion will be followed by the reception of the gifts of the Holy Spirit or the "infilling” of the Spirit, which almost always manifests through the practice of speaking in tongues. ${ }^{25}$ Anderson also identifies the centrality of mission and evangelism as practices that mark the charismatic churches. These are linked with baptism in the Holy Spirit and anchored in another belief about is the "soon coming or return of Jesus Christ.” Although all the Pentecostal Charismatic churches generally demonstrate these belief and practices, they differ in their approaches to expressing them.

In order for us to be able to identify the innovations the CRMI is making to adapt to the American religious ethos, it is very important to mention some key elements that define Ghanaian Pentecostal religious worldviews and practices. In his book Akan Witchcraft and the Concept of Exorcism in the Church of Pentecost, Opoku Onyina sheds light on how the Church of Pentecost in Ghana responds to members' challenges with evil spirits. Within the Ghanaian traditional religious worldviews, there exist certain malevolent spirits, whose activities bring about calamities in the lives of human victims. Onyina, for instance, asserts that the Ghanaian Pentecostal narrative on "witch

\footnotetext{
${ }^{25}$ Anderson, An Introduction to Pentecostalism, 187-206.
} 
demonology, which is heavily based on Akan holistic notions of salvation and energized by Western proponents of prosperity and deliverance ministries, posits that there is a specific supernatural cause for suffering in a person's life” ${ }^{26}$ As a result, what are elsewhere considered as misfortunes, including ill health conditions such as reproductive disorders, fibroids, diabetes, hypertension, barrenness, recurrent sexual dreams, mental disorders, epilepsy and sudden deaths, ${ }^{27}$ are understood as manifestations of spiritual attacks on believers. Asamoah-Gyadu argues that the Charismatic churches in Ghana are influenced by these indigenous worldviews in their appropriation of religious ritual to ameliorate ill-health. ${ }^{28}$ Thus in addition to natural or scientific views about the causes of ill-health, Charismatic churches in Ghana also take into consideration the African indigenous worldview that links ill-health to harmful supernatural causal agents. Some of these causes include the "'breach" of a taboo or customs, disturbances in social relations, hostile ancestral spirits, spirit possession, demonic possession, evil machination and intrusion of objects, “evil eye,” sorcery, and afflictions linked to gods. ${ }^{29}$

In his study about Ghanaian charismatic churches, Paul Gifford also discovered that, very common among Ghanaian Charismatic practices are the phenomena of

\footnotetext{
${ }^{26}$ Opoku Onyina, “Akan Witchcraft and the Concept of Exorcism in the Church of Pentecost,” PhD Thesis (University of Birmingham, Birmingham, 2002), 337.

27 B. M. Sackey, New Direction in Gender and Religion: Changing Status of Women in African Independent Churches (Oxford: Lexington Books, 2006), p 116.

${ }^{28}$ Asamoah-Gyadu, African Charismatics, $166{ }^{28}$; E. M. Kekesi, "Traditional and Christian Healing in Ghana: A Case Study in the Asuogyaman District,” M.Phil Thesis (University of Ghana, Legon, 1996), 34. See also, Yohanes K. Ahiabu, "Healing and Deliverance in Church Growth: The Case of the Global Evangelical Church from 1991 - 2011,” MPhil Thesis (University of Ghana, Legon, 2013), 47.

${ }^{29}$ Erhabor Sunday Idemudia, “Mental Health and Psychotherapy 'through' the Eyes of Culture: Lessons for African Psychotherapy,” http://www.inst.at/trans/15Nr/02_7/idemudia15.htm.Accessed 23 July, 2012.
} 
miracles, healing and deliverance (in the form of casting out demons), prophecy, the gospel of prosperity, and rituals relating to notions of success and financial breakthroughs. ${ }^{30}$ Gifford also mentions practices such as laying hands on believers, spontaneous but regular praying and singing at worship and outside worship centers, selling and administering of sacred oil used for anointing believers as a form of prayer aid, positive confession, "sowing of (financial) seeds in church ministers," and many other practices. Regarding the religious beliefs and practices of Ghanaian charismatic churches, Asamoah-Gyadu explains that the key "soteriological goals" of Charismatic Pentecostals include the realization of transformation and empowerment, healing and deliverance, and prosperity and success in the lives of believers. ${ }^{31}$ The CRMI shares these traits. But in its efforts to localize in South Florida, it has found it necessary to deemphasize some of the elements that define its Ghanaian Charismatic religious heritage. It has also adopted some elements indigenous to the USA in order to accommodate the spiritual and cultural needs of its American members. This study examines how these Ghanaian Oriented Charismatic Christian religious beliefs and practices are being transplanted in North America and to what extent they have been reinvented to suit the

\section{Ghanaian Charismatic Churches and Global Mission}

The growing literature on Neo-Pentecostalism has touched on how some of these churches in Ghana and Africa in general endeavor to spread the gospel beyond Africa,

\footnotetext{
${ }^{30}$ Anderson, An Introduction to Pentecostalism, 44-112; See also, Cephas N. Omenyo, "Man of God Prophesy Unto Me: The Prophetic Phenomenon in African Christianity" Studies in World Christianity 17, 2011, 30-49.

${ }^{31}$ Asamoah-Gyadu, African Charismatics, 132-133.
} 
especially in Europe and North America. This is why Allan Heaton Anderson describes them as "inherently expansionist or missionary." ${ }^{32}$ The earliest manifestation of African Pentecostalism on the global stage was the presence and the missionary activities of African Instituted Churches in Europe and North America. In contemporary times African Charismatic Churches and their Latin American counterparts are changing the religious histories of the West, especially the United States of America. ${ }^{33}$

The global flow of African Charismatic Christianity, in particular, has been attributed to the dynamism and fluidity of Pentecostal traditions. The dynamism with which the Charismatic churches approach their global missionary activities is embedded in what Allan Anderson refers to as their "global Charismatic 'meta-culture' that transcends locality and denominational loyalty." ${ }^{34}$ It is in the light of this meta-cultural phenomenon identified with Charismatic churches that Birgit Meyer asserts that, "Pentecostalism is always in the process of becoming a matter of movement performance rather than a fixed religious system backed up by frozen structures of authority.”35 In studying the role of lay Ghanaian immigrants in the rooting of African Charismatic Christianity in America, we will see how this dynamism and fluidity plays out in the

32 Allan Heaton Anderson, To the Ends of the Earth: Pentecostalism and the Transformation of World Christianity (Oxford University Press, 2013), 62.

${ }^{33}$ Ogbu Kalu, African Pentecostalism: An Introduction (New York: Oxford University Press, 2008), 284285.

${ }^{34}$ Anderson, Introduction to Pentecostalism, 179-180.

35 Birgit Meyer, "Pentecostalism and Globalisation" in Allan Anderson, Michael Bergunder, Andre Droogers, Cornelis Van Der Laan (eds) Studying Global Pentecostalism: Theories and Methods, (Berkeley: University of California Press), 121-122. 
religious lives of Ghanaians, who, in the face of migrant related challenges create their own spaces for expressing their Charismatic Christian spirituality.

In his book The African Christian Diapora: New Currents and Emerging Trends in World Christianity, Afe Adogame uses a thematic approach to explore the proliferation of African Christian communities in the Europe and North America. He uses Nigerian and Ghanaian cases (but with more emphases on Nigerian) to show how migration processes shape religious activities of African immigrants in their various host countries. According to Afe Adogame, the migration system theory ${ }^{36}$ and transnational migration ${ }^{37}$ theories are relevant to the understanding of the movement of African immigrants and their involvement in activities of African Christian communities in Europe and America. The migration system theory suggests that unfavorable conditions in the host communities where African immigrants live partly influenced their involvement in religious activities. The transnational theory posits that organizations such as Ghanaian Charismatic churches, either in the homeland or host countries and or their leaders, facilitate the migration processes of some African immigrant. Adogame notes how the will-be immigrants and immigrants locate themselves in a web of religious ritual, before and during migration processes. He argues that African immigrants, particularly, those in

\footnotetext{
36 The migration system theory, which explains migration process from multi-causal perspectives, is described as a set of places linked by flows and counter flows of people, goods, services, and information, which tend to facilitate other exchanges, including migration between places. See A. L. Mabogunje, “System Approach to Rural-Urban Migration” Geographical Analysis 2 (1970), 1-18.

${ }^{37}$ Transnational migration theory describes the movement of people on a regular basis across national borders requiring commitment of time by migrants and facilitated by either national government representatives and multi-national institutions or modest individuals as well as those initiated by political, cultural and religious groups. See Alejandro Portes, "Towards a New World: The Origins and Effects of Transnational Activities,” Ethnic and Racial Studies, 22.2(1999), 463-477.
} 
Germany, continue to appropriate varying religious rituals in order to succeed in the host countries, whether as a transit point or considered as their final destination.

According to Adogame, the centrality of religious rituals in the lives of African immigrants prior to their departure from the home country shapes immigrants' involvement in religious communities. The involvement in religious activities in the diaspora serve as a continuity of religious processes initiated prior to departure. It can be concluded that the emergence of distinctive independent African Charismatic churches in the diaspora is a continuity of pre-migration religious rituals. ${ }^{38}$ Adogame's transnational theory offers no leads in this present study. The home churches in Ghana played no official role in the migration of the founders to the USA. But his idea that pre-migration religiosities play out in the religious dispositions of migrants in the host land sheds great light on the religious considerations that pushed the founders of the CRMI to initiate the worshipping cell.

Afe Adogame's The African Christian Diapora also sheds light on how prevailing circumstances in both the homeland and host community shape religious practices of the African Christian communities in diaspora. The Ghanaian prospective immigrants are located within certain prevailing socio-cultural, religious, political and economic contexts and worldviews. While some of these contexts are favorable to the prospective immigrants, others were experienced as very unbearable. These contexts therefore define the push or pull factors in the Ghanaian immigration process. ${ }^{39}$ Among these push or pull

\footnotetext{
${ }^{38}$ Adogame, The African Christian Diaspora, 16-36.

${ }^{39}$ Adogame, The African Christian Diaspora, 7, 16-20.
} 
factors are: unemployment, unsuccessful marriages, unfavorable working conditions, higher educational opportunity, better job conditions, desires to get united with one's family members and the like. Adogame, however, discovered that, regardless of push or pull factors, the Ghanaian immigrants almost always sought for spiritual intervention in their immigration.

Consequently, the prevailing settings of the home country define and shape what religious rituals are employed to remedy prevailing hardship or improve on members' socio-economic situations. ${ }^{40}$ Similarly, immigrants are sometimes faced with the same challenges in addition to those from which they have fled in their home countries. The new problems are generally linked to the immigrants' location in a different sociocultural, political and economic context. According to Afe Adogame, most Nigerian and Ghanaian immigrants (documented and undocumented, skilled or unskilled) in Germany have to battle with various problems they are faced with in the host country. Among these are lack of employment opportunities owing to their migrant or non-migrant status, discrimination at work places grounded on racial disparities, insufficient remuneration to support their families, continuous security checks with accompanying harassment, securing residential permits and many others. Adogame argues that these challenges do not only become the new challenges Ghanaian and Nigerian immigrants have to deal with through appropriation of different kinds of religious rituals, they also become determinants for inventing new religious practices to ameliorate them. ${ }^{41}$ The centrality of existing contexts in shaping the religious activities and rituals of the churches in their

${ }^{40}$ Adogame, The African Christian Diaspora, 41-42.

${ }^{41}$ Adogame, The African Christian Diaspora, 85-90. 
country of origin and the host country also resonates with Paul Gifford's conclusion that the socio-cultural, political, and economic woes were pivotal to understanding the rise and practices of Nigerian and Ghanaian new Christianity. ${ }^{42}$

The present study demonstrates many of these scholarly findings. But it argues that engaging migrant related challenges are not the only reasons for African migrants' participation in religious activities. African migrants with deep religious convictions yearn to express their spiritualties, challenges or not. They will therefore join churches or initiate domestic worshiping cells on their own, as the story of the CRMI will demonstrate. The changing of religious approaches to changing contexts re-echoes a unique characteristic of the Ghanaian and African Charismatic churches. Many scholars have identified the Charismatic churches as being very flexible in their approaches to adapting to the varying socio-cultural, economic and political settings within which they function. This dynamism, according to Allan Anderson, Paul Gifford, Cephas Omenyo, Kwabena Asamoah-Gyadu and many other scholars in mission studies, accounts for the rapid growth of the Charismatic churches. ${ }^{43}$ This is because their approaches to religious activities almost always respond appropriately to existential needs of their members. Allan Anderson, for instance, states that;

One of the reasons for the growth of the Pentecostal and Charismatic churches may be that they have succeeded where western founded churches have often failed- to provide a contextual Christianity in Africa. ...it is the ability of African Pentecostalism to adapt to and fulfil the religious aspirations that continue to be its main strength. An African style of worship and liturgy and a holistic Christianity that offers tangible help in this world as well as the next together

\footnotetext{
42 Paul Gifford, Ghana's New Christianity: Pentecostalism in a Globalizing Economy (Indianapolis: Indiana University Press, 2004), 19.

${ }^{43}$ Omenyo, Pentecost outside Pentecostalism 38,104 \&115.
} 
form a unique African contextualization of Christianity. This contextual Christianity meets needs more substantially than the often sterile Christianity imported from Europe. ${ }^{44}$

The flexibility with which the Charismatic churches operate, and their ability to shape their approaches to different socio-cultural contexts appears to be one of the effective tools in their missionary enterprises at local and international levels. Their flexibility, therefore, becomes a catalyst for satisfactorily remaining relevant, not only to their native Africans in the diaspora but also to non-Africans who have become the target of their mission activities in recent times. This is exactly the situation with the CRMI, whose leadership shows creativity and ingenuity in shaping a religious tradition founded primarily to provide spiritual needs of Ghanaian immigrants, to the needs of members who are not necessarily Ghanaians or even Africans.

The historiography of Ghanaian-organized religious presence in the USA dates back to the last quarter of the $20^{\text {th }}$ century. In sketching out the history of Ghanaian Christian presence in the United States of America, Afe Adogame identifies three major stages. ${ }^{45}$ The first stage and the earliest manifestations of Ghanaian founded Christianity in the West were identified with activities of Ghanaian migrants in the USA, who established branches of the mission-founded home churches. Moses O. Biney in his From Africa to America: Religion and Adaptation among Ghanaian Immigrants in New York studied the Presbyterian Church of Ghana as a case of one of the Ghanaian-founded Churches in the USA. According to Biney, the church was established in 1983 by some Ghanaians who became dissatisfied with the religious activities of the North American-

\footnotetext{
${ }^{44}$ Anderson, An Introduction to Pentecostalism, 122.

${ }^{45}$ Adogame, The African Christian Diaspora, 62.
} 
founded branch of the Presbyterian Church. As a Ghanaian Historic Mission Church founded abroad, their main objective was "to offer members the opportunity to worship in a manner similar to that in Ghana". ${ }^{46}$ Membership was limited to Ghanaians.

The founding of African Independent Churches (AICs) marked the second stage of organized Ghanaian Christian presence in the USA. During the earliest period of their formation in Ghana and Africa in general, the majority of the AICs were known and described as separatist, nationalist, "nativist" churches or protest movements. These labels were attributed to the AICs because some of them fashioned their religious activities in direct opposition to colonial administrations in the various African countries. As churches primarily founded by Africans for Africans, some AICs in America also restricted their religious activities to their African members. ${ }^{47}$ One of the earliest Ghanaian-founded AICs in the USA is the New York branch of Apostles Revelation Society (ARS). The ARS was founded in 1984 with the main objective of providing the religious needs of its members. Over the past thirty (30) years the church has expanded its membership scope to embrace non-Ghanaians and non-Africans. This has led to the opening of new branches in some other parts of the USA.

Except for the renewed commitment of the AICs to expand the scope of their religious activities to embrace non-Africans, neither the first nor second stages of the

\footnotetext{
${ }^{46}$ Moses O. Biney, From Africa to America: Religion and Adaptation among Ghanaian Immigrants in New York (New York: New York University Press, date), 65. See also, Moses Biney, "Singing the Lord's Song in a Foreign Land: Spirituality, Communality and Identity, in a Ghanaian Immigrant Congregation” in Jacob K. Olupona and Regina Gemignani (eds), African Migrant Religion in America (New York: New York University Press, 2007), 260.

${ }^{47}$ M. L. Daneel, Zionism and Faith- Healing in Rhodesia: Aspects of African Independent Churches (Gravenhage: Mouton\& Co., 1970), 10. See also, H. W. Turner, "A Typology of African Religious Movements," Journal of Religion in Africa 1 (1967), 17. “A Typology of African Religious Movements,"
} 
African Christian religious presence in the USA can be described as mission in reverse. According to Ogbu Kalu, the formation of African Independent Churches was primarily aimed at providing religious space for their immigrant members in the West. However, contemporary African Charismatic Churches with their Latin American-founded counterparts are changing the religious history of the West, especially the United States of America, in that they have turned the United States into one of their missionizing zones. $^{48}$

The Christian mission enterprise of Pentecostal Charismatic Churches from Africa represents the third stage of organized African Christian religious presence in the USA. As was the case with other African charismatic churches, the propensity to spread the gospel beyond their local boundaries is very central to Ghanaian Pentecostal Charismatic Churches. Birgit Meyer in her chapter, "Pentecostalism and Globalization” notes how Pentecostal and Charismatic churches envisage the world, their emphasis on spreading the gospel across the globe, and how they are reconstructing their concept of the world. ${ }^{49}$ She argues that though very much aware of local specificities, Pentecostals have a sense of the world as a space that contains many unfamiliar territories, yet is shaped by invisible principles that Pentecostals claim they can overcome. While Meyer's observation remains fundamental to understanding the global dimensions Ghanaian Charismatic Christianity has assumed, it is also significant to state that the status of being referred to as an international church is very central to the Charismatic churches at the local levels.

\footnotetext{
${ }^{48}$ Kalu, African Pentecostalism: An Introduction, 284-285.

${ }^{49}$ Meyer, “Pentecostalism and Globalization”, 114.
} 
The internationalization of Christian mission activities is vigorously pursued among the Ghanaian Charismatic churches in different ways. These churches have established many congregations outside the original home country of the church founders and or where the churches first begun. Dovlo observes that in Africa, especially, in Ghana, most of these Charismatic Churches have prefixed or suffixed the words "International," "Global,” or "Universal” to their names. ${ }^{50}$ Afe Adogame further explains that, apart from their naming patterns, the African Charismatic churches symbolically demonstrate their international outreach though the use of banners and countries' flags:

The conspicuous and symbolic display of global operational frameworks through the hoisting of flags (banners) at the pulpit and within the church vicinity forms another basic characteristic of African-led churches. Thus, from the least two to several colourful flags could be counted around the pulpit or the vicinity of the altar. Each flag represents a country to which the church has a branch or where there is some form of religious affiliation, or a body/group with which they have established ecumenical relationship. This add credibility or as an image booster to the local church. Apart from the aesthetic values that characterises such hoisting of beautifully colourful flags, it further symbolises their selfidentification as within global religious space. ${ }^{51}$

The international dimension African Pentecostalism has assumed is indicative of changing trends in the African Pentecostal Charismatic Christian missionary enterprise. These churches keep progressing in terms of their outreach. First they shift their operations from the local sphere to the national sphere. Then, they move from the continental sphere to the global sphere. One concept that scholars have tied to the international aspect of African Pentecostal Charismatic Christianity is "reverse mission."

\footnotetext{
${ }^{50}$ E. Dovlo, “African Culture and Emergent Church forms in Ghana,” Exchange: Journal of Missiological and Ecumenical Research 33 (2004), 43- 44.

${ }^{51}$ Adogame, The African Christian Diaspora, 150.
} 
Although copiously used to explain different mission phenomena, the concept captures the Christian mission relationship between some West African countries and the West. The reverse mission concept explains a new relationship that has developed in the history of Christianity where countries that once served as agents in transmitting the gospel have now become recipients of the gospel from their former recipients. Many scholars have explored the different ways in which mission is now "reversed. "Gerri ter Haar notes how, "Just as European missionaries once believed in their divine task of evangelizing what they called the Dark Continent, African Church leaders in Europe today are also convinced of Africa's mission to bring the gospel back to those who originally provided it.”52 Jacob K. Olupona and Regina Gemignani indicate how religious motivation is becoming very significant in shaping the migration of most African immigrants. They note how "a large percentage of African religious community leaders and members view their migration to the United States in the context of an evangelical mission to the West.”53 Olupona and Gemignani link this development to the tendency of African Charismatic and Pentecostal churches based on members' own assertion that all believers are potential evangelizers and prospective spreaders of the gospel. In this way, the churches encourage members to root new churches wherever they go. In other words, Olupona and Gemignani seem to suggest that the reverse mission process derives inspiration and supported by the Pentecostal teachings about the role of the worshippers as evangelists.

\footnotetext{
${ }^{52}$ Gerrie ter Haar, "Strangers in the Promised Land: African Christians in Europe," Exchange 24 (Feb. 1995), 1-33.

${ }^{53}$ Jacob K. Olupona and Regina Gemignani (eds), “Introduction,” in African Migrant Religion in America (New York University Press, 2007), 8.
} 
Birgit Meyer underscores the importance of media in the global spread of African Pentecostalism She also emphasizes how the goals of the missions are to reconvert Western people." 54 This initiative, she notes, is grounded on the assertion "that the generation following Western missionaries who spread the gospel to the 'heathen' have lost faith and succumbed to a process of un-churching..." ${ }^{55}$ Brigit Meyer suggests the need to examine, comparatively, the significant differences and similarities in the spread of African Pentecostalism across continents. ${ }^{56}$ Taking a clue from Olupona's observation that migrants travel with the sense of mission implanted in them, my focus in this study will be on the crucial roles migrants from Africa are playing in this reverse mission.

Afe Adogame evaluates how mission scholars are divided on the validity of reverse mission claims. He notes how, on the one hand, proponents of the reverse mission are of the view that the establishment of African Independent Churches and later, the Pentecostal Charismatic Churches in the West, constitutes a reverse mission. ${ }^{57}$ He also notes how, on the other hand, some other scholars argue that the African Christian religious presence in the West and the religious activities of the various churches are only responses to the need to provide the spiritual needs of their native African Immigrants in

\footnotetext{
${ }^{54}$ Meyer, “Pentecostalism and Globalisation,”, 119-120.

${ }^{55}$ Meyer, “Pentecostalism and Globalisation” 120.

${ }^{56}$ Meyer, “Pentecostalism and Globalisation” 120.

${ }^{57}$ Ursula Harfst, "The Program for Cooperation between German and Foreign Language Churches and African Churches in the Rhein-Ruhr-Region: Developments from 1999” in Afe Adogame, Roswith Gerloff and Klaus Hock (eds.) Christianity in Africa and the African Diaspora: The Appropriation of a Scattered Heritage (New York: Continuum International Publishing Group, 2008), 342. See also Afe Adogame, "Who Do They Think They Are? Mental Images and the Unfolding of an African Diaspora in Germany" in Adogame et al, (eds.) Christianity in Africa and the African Diaspora, 260.
} 
the USA. ${ }^{58}$ In analyzing the two sides of the reverse mission claims, it is important to consider the place of mission, the type or denomination of African Christianity and period in which the mission activities are being studied. My study will show that the two positions Adogame has identified can be reconciled. The CRMI originated as a response to the quest to meet spiritual needs of Ghanaian migrants. In the years that followed the creation of the cell that marked its origins, the founder linked the group with a church in Ghana. Furthermore, in order to expand the influence of the church in the USA the founder opened doors to non-Ghanaian migrants. This trajectory demonstrates a trend in which migrant worshipping cells function as launching pads for the reverse missions of churches from Ghana.

It is worthy to note that the existing literature on African Christian mission presence in the diaspora has been motivated by different objectives. As a result, the authors were grounded in different theoretical perspectives, leading to different discoveries and conclusions. One central aspect of African Christian missions in the diaspora is the role of ordinary lay immigrant worshippers in their origins and evolution. However, in the ongoing discussion about the emergence of African Christian missions abroad, the role of lay immigrants in the initial stages of their formation and through their growth as full-fledged Christian ministries appears to be treated only cursorily. This study is an attempt to fill this gap.

58 Roswith Gerloff, “Churches of the Spirit: The Pentecostal/ Charismatic Movement and Africa's Contribution to the Renewal of Christianity” in Adogame et al. (eds.) Christianity in Africa, 208, 212, See also, Dapo Asaju, “Colonial Politicization of Religion: Residual Effects on the Ministry of African-Led Churches in Britain,” in Adogame et al. (eds.) Christianity in Africa ,285, See also Harfst, "The 'Program for Cooperation,"in Adogame et al. (eds.), Christianity in Africa, 337. 


\section{Theoretical Perspective}

The data I gathered on the CRMI revealed two major themes. One theme is that the role of migrants in the reverse mission of African Charismatic churches in the West, especially in the USA, is indispensable. For the most part, it is lay migrant worshippers who initiate the religious groups that eventually become the diaspora extensions of churches in Africa. Only after these migrant worshipping cells are formed do the initiators reach out to churches in the homeland for guidance. Often these are churches they belonged to before their migration to the West. The churches in the homeland view these invitations as an opportunity to expand their influence globally.

Also, it is migrants who welcome agents of these churches, who constitute the bulk of their membership, and who guide the homeland churches, after they take over the migrant-originated cells. The second theme is that only after their rooting in the diaspora do these churches begin to recruit members from the host community, developing a reverse mission agenda and motivated by the quest to expand their influence. However, this move necessitates introduction of certain changes to the emerging religious community in the host country, which becomes an extension of the homeland church. To accommodate the needs of the members from the host community, the churches deemphasize some aspects that are indigenous to their place of origin and add elements from the host community. In developing these two main themes, I have engaged the two concepts as I have considered them necessary for our reflection. I have analyzed these concepts on their own merit. But I have also examined them in terms of how they can be linked together to provide the framework for understanding the CRMI's history and 
activities as parts of a coherent whole. The concepts are the "invention of traditions" and agency.

We turn our attention to the first major concept, that of invention of traditions. This thesis attempts to understand the worship tradition of the CRMI as an invented Ghanaian Pentecostal tradition. The thesis develops the concept of the invention of traditions to explain how and why this process became necessary in this church. It also discusses the features of this invented Ghanaian Pentecostalism as demonstrated in the religious activities of CRMI. Eric J. Hobsbawm and Terence Ranger were the first to apply the concept of invention of traditions as a theoretical framework to the study of different cases of changes and innovation made to cultural systems across the world. In their book, The Invention of Tradition, they define invented traditions as "a set of practices normally governed by overtly or tacitly accepted rules and of a ritual or symbolic nature, which seek to inculcate certain values and norms of behavior by repetition, which automatically implies continuity with the past. In fact, where possible, groups normally attempt to establish continuity with a suitable historic past." ${ }^{59}$ In its traditional usage, this concept refers to a set of societal norms, institutions and practices that have been deliberately or inadvertently re-established by a community which seeks to forge a link with a past, history or practice. Two factors can heighten a community's predisposition to invent tradition. First, when radical or drastic changes in society destabilize the social basis of existing norms and practices, new conditions emerge for which the old traditions might not be suitable. As the existence of communities depend

\footnotetext{
${ }^{59}$ Eric Hobsbawm, "Introduction: Inventing Traditions" in Eric Hobsbawm and Terence Ranger (Eds.) The Invention of Tradition (Cambridge: Cambridge University Press, 1983), 1.
} 
on their traditional institutions and norms appearing to be relevant, it then becomes imperative for the leaders to come up with new traditions. Second, when an old tradition becomes irrelevant or when its custodians have died off, it becomes necessary to invent a new one. ${ }^{60}$ In these situations, the invention of tradition occurs as a response to social and cultural change.

Inventing of tradition is really a process of socio-cultural rejuvenation. In the context of the present study, the leadership of the CRMI introduced innovations into the Ghanaian Pentecostal tradition when its practices were found to be no longer suitable in the face of the new conditions the Church encountered in South Florida. As the existence of the church depends on the relevance of its practices, it became necessary for the leaders to create new practices. A sense of “immutability" is a crucial element that defines an "invented tradition." ${ }^{61}$ In other words, even though a tradition is said to be “invented” it retains the same symbolic value, function, force or meaning held by the old tradition. The innovations introduced into the tradition of the CRMI by its leaders do not make the tradition any less Pentecostal. They retain the same symbolic value, function, force or meaning held by the old tradition.

In his analysis of European colonial relations with Africa and other former colonies, Gaurav Desai argues that invention of tradition "is at ones an act of faking and

\footnotetext{
${ }^{60}$ Hobsbawm, "Introduction: Inventing Traditions" 4-5. See also Terence Ranger, "The Invention of Tradition in Colonial Africa" in Hobsbawm and Ranger, (eds.), Invention of Tradition (Cambridge: Cambridge University Press, 1983), 211-263.

${ }^{61}$ Hobsbawm, “Introduction,” 9.
} 
an act of making." ${ }^{62}$ Gaurav Desai also explains that the process of invention does not necessarily mean creating something new out of nothing. For him, invention of traditions also entails designing or generating something (approaches and processes of doing things or models for explaining a changing situation) new from existing one/ones with or without traces of their original historic old model. ${ }^{63}$ In this connection we must understand invention of tradition to mean synthesizing two or more traditions or values from unfamiliar origins into one distinct whole complex. The study shows how the CRMI's tradition is a synthesis of Ghanaian Pentecostal practices and meanings and the novel practices and meanings the leadership has adopted in the USA. The study will also show how North American cultural elements have been blended with Ghanaian Pentecostalism to create an entirely new religious complex. This is neither Ghanaian nor purely North American. Taken from this point of view, it can be said that the ability of African and Ghanaian Charismatic churches to respond adequately to the spiritual needs of congregations made up of people with diverse socio-cultural origins is grounded on their being able to invent new traditions.

We now turn our attention to the concept of Agency. This theory was first propounded in the 1970s by scholars such as Armen Alchian, Harold Demsezt, Michael Jensen, William Meckling and S. A. Rose. ${ }^{64}$ Although the theory was designed to explain problems that arose in areas of economics, it was found to be also applicable in other

\footnotetext{
62 Gaurav Desai, “The Invention of Invention,” Cultural Critique 24 (Spring, 1993), 119-142.

63 Desai, “The Invention of Invention,” 121-122.

${ }^{64}$ B. M. Mitnick, “Agency Theory” in R. E. Freeman and P. H. Werhane (eds.) The Blackwell Encyclopaedic Dictionary of Business Ethics (Maiden, MA: Blackwell, 1998), 12.
} 
social science disciplines. In this study we are concerned with the socio-anthropological meaning and use of the concept. We find this concept very applicable to our data. For sociologists and anthropologists, human agency is the concept that each human individual within a culture has the ability to determine and choose by free will his or her actions, beliefs, etc. This contrasts to the idea that we are completely governed by either nature or environmental factors (like culture), because we possess these innate capacity to think for ourselves. ${ }^{65}$ The underlying assumption is that individuals have power and express this through their thoughts and the actions they take.

The core challenge at the center of the fields of sociology and anthropology is the understanding of the relationship between structure and agency. Structure refers to the complex and interconnected set of social forces, relationships, institutions and elements of society that work together to shape the thought, behavior, experiences, choices, and overall life courses. In contrast, agency is the power people have to think for themselves and act in ways that shape their experiences and life trajectories. Agency can take either individual or collective forms. The debate about the relationship between structure and agency often comes up when sociologists and anthropologists study the lives of disenfranchised and marginalized populations. ${ }^{66}$

\footnotetext{
${ }^{65}$ Michael M. Cernea \& April L. Adams, Sociology, Anthropology, and Development: An Annotated Bibliography of World Bank Publications, 1975-1993 (World Bank Publications, 1994). Page number not available.

${ }^{66}$ Margaret S. Archer, Culture and Agency: The Place of Culture in Social Theory (New York: Cambridge University Press, 1988), 72.
} 
Many people, social scientists included, often slip into the trap of describing such populations as if they have no agency. I suggest in this study that the relative silence on the role of lay migrant worshippers in the reverse mission literature reflects this situation. The impression created is that only official agents of churches from Africa, through organized proselytizing activities, plant African churches in the West. The more common picture created is one of church agents from Africa flooding the West to cater to the spiritual needs of migrant populations. I argue in this work that as worshippers, African migrants have the power to initiate worshiping groups, independent of the direct involvement of their home churches.

The evidence shows that the starting point of these churches is the worshipping cells resulting from the initiatives of migrants with deep religious convictions. Their agency in the new situation is linked with how African evangelical churches impress upon their members that all of them are potential evangelizers and prospective spreaders of the gospel. Tacitly these home churches encourage members to plant new churches wherever they find themselves. Olupona notes how these churches frequently use the language of commerce and also of agriculture [sowing, tilling, planting, toiling and depositing] as metaphors for the establishment of new mission posts. Christian African migrants participate in reverse missions often define their mission as a response to the needs for the evangelization of people in the West, who had departed from the faith. 


\section{Conclusion}

The rise of Pentecostal Charismatic churches in the Ghanaian Christian religious scene and their subsequent spread to other parts of the world is quite phenomenal. Their presence in the various local and international communities across the world is not only affecting those religious landscapes, but also the socio-cultural, political and economic settings in which they are situated. In this chapter I have used different scholarly accounts to explore the manifestations of Ghanaian Pentecostal Charismatic Churches in Ghana and some parts of the Western world. It is evident that the internationalization of Christian religious activities is very central to the churches at their Ghanaian local origins. However, much of the success in their international enterprises is facilitated by existing Ghanaian immigrants living in the diaspora. This makes these lay immigrants a very significant aspect of establishing African Christian mission abroad; hence their influence in shaping the churches' religious activities with both African and Ghanaian worldviews. This chapter, therefore, lays the foundation for chapter three where I shall explore the establishment of CRMI in South Florida, taking into consideration the role of lay immigrants in its formation. 


\section{CHAPTER THREE}

\section{HISTORY OF CHRISTIAN RESTORATION MINISTRIES INTERNATIONAL IN MIAMI, FLORIDA}

\section{Introduction}

In this chapter, I shall trace the historiography of the Christian Restoration Ministries International as an example of a Ghanaian -founded Charismatic Church in the USA. I make a case for the role of African migrants in originating African migrant churches in the USA. I argue that the church originated through the agency of migrant worshippers. Only after its formation did the emerged leader turn to the homeland, Ghana to revamp a group he had already started there prior to his departure to America. He would link these two churches together at a later date, identifying the CRMI as an American extension of the Ghanaian branch. The chapter will demonstrate the agency of lay worshippers, not only in the origination of the church but also in the shaping of its evolution at various stages. The chapter begins with a description of the church and its worshipping community. I will then offer an account of its history and roles the various groups that emerged in the church, otherwise known as ministries.

\section{The Church as an Institution}

The Christian Restoration Ministries International (CRMI), the case for this research, is a Ghanaian-founded Charismatic church in North Miami, Florida. The church is located at 19255 NE $3^{\text {rd }}$ Ave. North Miami, Florida. The CRMI currently has about one hundred and twenty (120) members. Of this number forty (40) members are men, fifty (50) are women, and thirty are children. The children are the offspring of the adult members. The 
majority of the members are between twenty-five (25) and fifty (50) years old. Some members are as old seventy (70) years. Others are as young as five (5) years old. The majority of the adult members are working class people. Worshippers come from different ethnic backgrounds, including Ghanaians and other African ethnicities, North Americans, Caribbean, Indians, Caucasians and people from Latin America.

As stated earlier. The church is organized into various groups known as "ministries.” Each ministry has a specific responsibility. These ministries perform their different but related roles in the church sometimes simultaneously, to enhance its smooth running. Among these groups are the praise and worship group (choir), whose main responsibilities are "to raise people who are musically oriented and to lead the congregation before the throne of God through worship, praise, song, instrumental expression and adoration." ${ }^{67}$ There is the women's ministry, whose responsibility is "to help women, both in and outside the church to meet their spiritual, emotional, and intellectual needs, regardless of their stages in life or their cultural backgrounds.”68 Men's ministry is a group of men in the church who meet to encourage men through prayer and other social activities, "demonstrating mutual love, respect, and reverence for God and His house, our wives, children, families, so that they can develop into men of valor and leaders in their homes and communities." ${ }^{69}$ The prayer ministry "is a group of individuals who lead congregational prayers. The ministry is also responsible for training

\footnotetext{
${ }^{67}$ Eyim-Danquah, Emmanuel "History of the Christian Restoration Ministries International" www.CRMIus.org, Accessed on November 20"th 2015.

${ }^{68}$ Eyim-Danquah, Emmanuel "History of the Christian Restoration Ministries International" www.CRMIus.org, Accessed on November 20 $0^{\text {th }}, 2015$.

${ }^{69}$ Eyim-Danquah, Emmanuel "History of the Christian Restoration Ministries International" www.CRMIus.org, Accessed on November 20 ${ }^{\text {th }}, 2015$.
} 
a team that specializes in prayer. This team is called the prayer warriors. The team's work is to assist all "aspects of the church's life that call for prayer and spiritual encouragement." ${ }^{70}$ In addition, there is a children's ministry, whose goal is "to demonstrate the "love of God to children through age 12, both inside and outside the Church,” by providing Sunday School, special services, activities, games, snacks, devotionals, crafts, and various other "Christ-centered activities"71 If all of these were merely references, not quotes, noting the first and last reference would be enough. But all quotes should have notes, even if they are all to the same source.

Also, the youth ministry is a group of young people, who were brought together to "demonstrate the love of God to teens both inside and outside the Church," ${ }^{2}$ by organizing youth events, meetings, and activities with a Christian focus. The outreach ministry is a group of worshippers charged with evangelism, discipleship, ministry, fellowship, and worship. According to the tradition of the Church, these roles constitute the five functions of a church as stated in the New Testament. The Senior Pastor heads the outreach ministry. Finally, there is the care ministry, whose role is to extend the Senior Pastor's care and love to members. Members of this group reach out to people in

\footnotetext{
${ }^{70}$ Eyim-Danquah, Emmanuel "History of the Christian Restoration Ministries International" www.CRMIus.org, Accessed on November $20^{\text {th }}, 2015$.

71 Eyim-Danquah, Emmanuel "History of the Christian Restoration Ministries International" www.CRMIus.org, Accessed on November 20 2015.

${ }^{72}$ Eyim-Danquah, Emmanuel "History of the Christian Restoration Ministries International" www.CRMIus.org, Accessed on November 20 2015.
} 
need, whom the pastor cannot reach by himself, through one- on- one visit, or by telephone calls." ${ }^{73}$

With the support of these ministries, the church is run under the administrative and ministerial leadership of the Rev. Dr. Emmanuel Eyim-Danquah, Pastor, Mrs. Charlotte Eyim-Danquah, Minister/Pastor Ralph Eyim-Danquah, Ministers Emmanuel Eyim-Danquah Jr. and Enoch Eyim-Danquah. Mrs. Eyim-Danquah, the wife of Minister/Pastor, is a member of the prayer warriors. She is also the leader of the prophetic prayer conference, one of the Church's important religious activities. This leadership scheme identifies the church as family-owned; in other words the church organization is controlled by this single (Eyim-Danquah) family. ${ }^{74}$ This leadership pattern is one of the first signs of innovation one notices about the CRMI. This is in the sense that the church reshaped its leadership style from the previous communal structure to a private one. Having described the CRMI's worshipping ministries, I proceed with the story of its origins and historical evolution in the next section.

\section{The Story of the Church's Origins}

The North American religious landscape has witnessed inflows of Ghanaian Christian forms for the last three decades. These transnational religious in-flows have been motivated by different factors. Among these factors is the desire to create religious spaces for Ghanaian Christians, who could not find religiously satisfactory homes in the

\footnotetext{
${ }^{73}$ Eyim-Danquah, Emmanuel "History of the Christian Restoration Ministries International" www.CRMIus.org, Accessed on November 20 2015.

${ }^{74}$ Adogame, The African Christian Diaspora, 117.
} 
American branches of the historic mission churches they had affiliated with, prior to their departure from Ghana. The story of the New York Branch of the Presbyterian Church of Ghana, which was founded in 1985, illustrates this factor. ${ }^{75}$ This factor explains the creation of many Ghanaian churches which represent the first phase of the Ghanaian Christian presence in the United States of America.

The second phase is represented by the formation of African Instituted Churches in cities of the USA. The motives behind creating these churches were similar to those linked with the formation of the historic missionary-established churches in America. These Ghanaian-founded churches were transplanted in the USA, primarily to cater to the spiritual needs of their members who had migrated to the USA for different reasons. Initially these American extensions of African Initiated Churches limited their religious and membership to only Ghanaian migrants. Recently, they have begun to reach out to non- Ghanaians, including other Africans and Americans, especially African Americans. The Church of the Apostles Revelation Society, founded in 1984, is one case in point.

The formation of Ghanaian Charismatic churches in the USA represents the third phase in the history of the Ghanaian Christian presence in the USA. Some of these churches have been founded by missionaries from Ghana's Charismatic churches embarking on a global expansionist agenda. Many of them have established branches not only in the USA but also in some parts of Europe. What is more typical, however, is the practice of lay Ghanaian immigrant worshippers, most of whom were not Christian ministers before arrival in the USA, initiating these churches as prayer cells in their

\footnotetext{
${ }^{75}$ Biney, From Africa to America, 68.
} 
homes. As these cells blossom into churches over the years, the founders would then reach back to the homeland, inviting renowned Charismatic religious leaders to come and take over the churches as their extensions.

The opposite also happens sometimes, in that some founders of churches in the diaspora extend their influences into Ghana, to initiate local branches. ${ }^{76}$ Whatever the trajectory demonstrated, the point here is that lay practitioners play a more important role in the rooting of Charismatic churches in the USA that they are credited for. In the discussion that follows I shall trace the historiography of the Christian Restoration Ministries International, an example of a Ghanaian-founded Charismatic church in the USA, showing how the church originated through the agency of migrant worshippers seeking to find a space to express their spirituality. Only after its formation did the leader turn to the homeland to revamp a group he had already started there. At a later date he would link these two churches together. The objective of the chapter is to demonstrate the role of lay immigrants in originating Ghanaian Charismatic churches in the USA.

\section{Christian Restoration Ministries International (CRMI)}

The beginning of Christian Restoration Ministries International (CRMI) is linked with the initiatives of some Ghanaian immigrants who came to the USA primarily in search of greener pastures. The church emerged out of the efforts of these immigrants to create an atmosphere for satisfying their spiritual needs. According to Rev. Dr. Emmanuel EyimDanquah, one of the founding members and the current Head Pastor of the church, the CRMI started as a prayer cell that regularly met in his living room for one (1) year.

\footnotetext{
${ }^{76}$ Adogame, The African Christian Diaspora, 62.
} 
Three families; the pastor's, the Aryee, and the Adu families came together and initiated the prayer cell. As many other Ghanaians joined them, the group started to grow bigger. The founders then decided to transform the prayer cell into an official church. In 2000 they officially inaugurated this church. The emerged leader and Pastor of the church, Rev. Dr. Emmanuel Eyim-Danquah explained that he was trained as a church minister, and had worked as a full-time minister prior to his departure from Ghana, his home country. However, the reason for his migration with his family to America has nothing to do with founding of a church. He and his family left Ghana for America as any other ordinary Ghanaian immigrants to search for better conditions of living. When his family and two other Ghanaian families came together to hold weekly prayer meetings at his home, the main objective was to create an opportunity for them to pray in order to satisfy their spiritual needs. This is because they did not receive their desired spiritual satisfaction from the American churches they belonged to during the initial stages of their settlement in Miami. A background description of these three families is in order at this point, as it will shed more light on their original motivations.

\section{Rev. Emmanuel Eyim-Danquah and His Family}

Reverend Dr. Emmanuel Eyim-Danquah, Ghanaian-born and currently the Head Pastor of CRMI, said he became a born-again Christian, that is, he converted into the Assemblies of God, a Charismatic church, on April $8^{\text {th }}$ in 1976. According to him, he received his pastoral calling on July $7^{\text {th }}, 1977$, about a year and three months after his conversion, he had an encounter with the Holy Spirit. It was during this encounter that he received his calling to priesthood. The Holy Spirit also directed Eyim-Danquah to enroll 
in The Assemblies of God Bible School in March 1984, and to train as a pastor. Eyim-Danquah graduated in August, 1986 and was ordained as a pastor of the Assemblies of God. During his two and a half years as a pastor in Ghana, Eyim-Danquah opened new branches of the Assemblies of God church in different parts of Ghana. Rev. Eyim-Danquah said he broke away from the Assemblies of God Church in August 1989, so that he could form his own church. He named the church the Christian Restoration Ministries. He stated that apart from leading his own infant church as a pastor, he regularly preached at different Charismatic churches in Ghana. He also travelled to foreign countries upon invitation by leaders of Charismatic Churches there. These activities gave him some background reparation in "church planting," "switch of pulpit or change of altars" ${ }^{77}$ and in working as a pastor in foreign countries.

On August $13^{\text {th }}$, 1996, Eyim-Danquah, his wife, and three children immigrated to Miami from Ghana, driven by the quest for better conditions of living. A pastor of the USA branch of the Assemblies of God, living in Miami, sponsored the immigration of Eyim-Danquah and his family, and hosted them when they arrived. Pressured to return the favor of his sponsor, Eyim-Danquah re-joined the Assemblies of God in Miami. Eyim-Danquah also explained how he had no qualms about re-joining the Assemblies of God because at that time he had no intentions of creating his own religious

\footnotetext{
${ }^{77}$ This is a practice where Christian ministers invite their colleague minister to preach or perform any other religious roles within the same church denomination or different denomination and in some case different church typology. Usually, this provides opportunity for the lesser known minister to minister before a big congregation, thereby giving them exposure. In some cases, smaller denominations invite well-known ministers to their congregation in other to pull numbers into the church as well as making the smaller congregations popular.
} 
community."78 For the first three years of their stay in Miami, Eyim-Danquah and his family attended the Assemblies of God and other American--founded churches. The decision to join the Assemblies of God Church during their early periods of settling as immigrants enabled their cordial relationship with the colleague pastor. Their membership of the Assemblies of God and visits to other American-founded churches also exposed them to the South Floridian Christian Religious ethos. This knowledge would come in handy later when Eyim-Danquah would decide to create his own worshipping cell.

In January of 1999, Rev. Eyim-Danquah and two other Ghanaian families, the Aryees and the Adus, initiated a one and half hour weekly prayer session. They would meet every Friday evening for one and half hours of prayer and singing of devotional hymns. Explaining what prompted them to initiate this cell, Rev. Dr. Eyim-Danquah said his vocation as a pastor, sensitized him to the inadequacy of American-founded churches in Miami, in meeting the spiritual needs of his young children. American churches, he argued, appear to be "too spiritually dead" to nurture his growing children spiritually. The weekly devotional sessions were therefore intended to supplement the spiritual nourishment offered him and his children by the American Churches they attended.

Elaborating on the "spiritual dryness" in American churches, Eyim-Danquah explained how the duration of American devotional sessions was short, compared with the lengthy sessions that are typical of Ghanaian services. He lamented how this situation can stifle the spiritual growth of a child in America, given all the "temptations" American

\footnotetext{
${ }^{78}$ Emmanuel Eyim-Danquah, "Interview," November 24 $4^{\text {th }}$, 2015, at the office of Christian Restoration Ministries International Miami, Florida.
} 
society exposed children to. He listed the temptations as follows: sexual promiscuity, rampant usage of drugs, excessive consumerism, and "too much freedom." While the two families who joined him shared the same sentiments, they emphasized other considerations, considerations that spoke to their specific migration situations. The Aryee family argued that having escaped socioeconomic hardship in Ghana to come to America, which they saw as a greener pasture, they needed the "hand of God" in their lives, if they were to secure the prosperity they were seeking. The three families linked their quest for a more intense form of spirituality to the challenges they were experiencing prior to their departure and at that time in Miami. These were linked to their quests for their legal residence and their need for good jobs in their areas of training. Accordingly, the three families resorted to holding the weekly prayer meetings as a process of seeking spiritual solutions to the problems facing them.

The fact that the cell was comprised of Ghanaian families offered the three families the assurance that the children would grow up having enough exposure to "Ghanaian ways of doing things and of worshipping" to counter the adverse effects of the malcontents of American youth they were exposed to. A crucial point to note here is that although Rev. Eyim-Danquah was a pastor, he was not initially motivated by the quest to minister to worshipers, in creating this cell. As he pointed out, their main objective for migration to the USA was to find better living conditions. ${ }^{79}$ He and the other families' major concern was the need for a more suitable space for meeting their spiritual needs. Another point to note here is how religious and ethnic considerations interacted to push

\footnotetext{
${ }^{79}$ Rev. Dr. Emmanuel Eyim-Danquah stated that when they arrived in the USA, his wife, who later trained as a health care provider, was doing her own business as he was waiting on the Lord for the right job.
} 
them towards this project. Their move is typical of many African migrants who settle in the West. A difficulty in fitting in with the religious practices of the churches in their host lands and the quest to fellowship with others from the homeland explains why most African (and Ghanaian immigrants) form prayer cells. These prayer cells blossom into immigrant churches.

\section{Founding Christian Restoration Ministries International (CRMI)}

When news of the prayer cell's creation reached other Ghanaian migrants, they joined the meetings. Led by the three families, the group decided to launch into a fully organized church. The church was registered with the State of Florida on November 17, 1999. On January 3rd, the first Sunday of the year 2000, the church was officially launched at Davie (a south Florida community) with ten people. These comprised eight Ghanaians and two Caribbean people. The founders decided on the same name Rev. Eyim-Danquah gave the Ghanaian church which he started seven years before his migration to America, Christian Restoration Ministries. Rev. Eyim-Danquah explained that while his Ghanaian church was named Christian Restoration Ministries, they added the suffix “International” to the name of their American church in order to reflect the international space within which he was operating.

The church at this stage adopted its mission statement that reads: "To glorify God, by leading people to know Jesus and the benefits of His family; equipping them as true disciples to serve both in the Church and in the world." ${ }^{80}$ Concerning this, Rev.

\footnotetext{
${ }^{80}$ Eyim-Danquah, Emmanuel, "History of the Christian Restoration Ministries International" www.CRMIus.org, Accessed on November 20" 2015.
} 
Eyim-Danquah claims he has observed that the worship of God as seen in the disciples of Jesus Christ has for a long time degenerated and the Church of Christ has continued to lose its mandate among men and women. He therefore saw the rise of his church as an opportunity to bring about "restoration" to the church of Christ through the nurturing of identified ministries among believers and utilizing these "ministries" to bring total spiritual and physical transformation in the lives of people. It is the need for restoration of Christianity to the apostolic tradition that informed the wording of the church's name.

In search of a more conducive place of worship, the church was relocated to Miramar after the group had spent one year at the Davie location. The relocation also became necessary as the membership grew and there was the need to acquire a larger space to accommodate the ever increasing worshipers. The church later had to move again to its current location at Miami Gardens, to a 120 seating capacity auditorium with office complexes. They bought this premise. At later dates the Aryee and Adu families relocated to other states, leaving Rev. Eyim-Danquah solely in charge of affairs.

The church also adopted the following as its statement of faith:

Our church accepts the Holy Scriptures as the revealed will of God and teaches fundamental truths as our doctrine:

- $\quad$ The Bible is the inspired Word of God and the revealed will of God.

- $\quad$ There is one true Godhead comprised of the Father, Son and Holy Spirit. All are co-equal and co-eternal. Jesus Christ, God manifest in the flesh, is the second member of the Godhead.

- $\quad$ Man was created in God's image. By voluntary transgression he fell and his only hope of redemption is in Jesus Christ the Son of God.

- Man's only hope of redemption is through the shed blood of Jesus Christ. On the cross Jesus Christ became sin and sickness, providing both salvation and healing for all mankind. This salvation comes by believing in your heart that God raised Jesus from the dead and confessing with your mouth, Jesus as Lord. The inward evidence, to the 
believer, is the direct witness of the Spirit. The outward evidence to all men is a life of true holiness and love. Salvation is by faith in Jesus Christ and not by human works; however, our works are evidence of our faith and will determine our rewards in eternity.

- Baptism in water is a declaration to the world that a believer has died with Christ and that they have been raised with Him to walk in newness of life.

- We remember what Jesus did for us by celebrating the Lord's Supper. We do this by eating the bread and drinking of the cup.

- $\quad$ All believers should seek the Baptism in the Holy Spirit. The promise has been made to each believer. Our responsibility is to ask for and receive the baptism, according to the command of Jesus Christ. With this comes the empowerment for life and service. This experience is distinct from and should follow the new birth.

- $\quad$ Speaking in other tongues as the spirit gives utterance is the initial evidence and physical sign of the Baptism in the Holy Spirit. The subsequent manifestation of spiritual power in public testimony and service, and a holy life, is further evidence of this baptism.

- $\quad$ The Church is the Body of Christ. Each believer is an integral part.

- We believe in total prosperity for each believer (Spiritual, Mental, Physical, Financial).

- Jesus is coming again to gather all His saints to Heaven.

- We believe there is an eternal separation from God for those who have not accepted the redemption work of Christ. They will burn in the lake of fire.

- We believe in the return of our Lord Jesus Christ with His saints from Heaven to rule and reign for 1000 years on earth as the Scripture promised. ${ }^{81}$

These statements of faith have in diverse ways shaped the church's ritual processes and religious expressions. These statements inform its programs and activities, such as the organization of prayer meetings, preaching the gospel, the phenomenon of prophetic utterances, healing, deliverance (ministering to people), praise and worship, money offering, and other social services. An incident, which occurred in 2006, would change the trajectory of this Ghanaian originated church. This incident also demonstrates, on another level, the agency of worshippers in the shaping of the church's evolution.

\footnotetext{
${ }^{81}$ Emmanuel Eyim-Danquah, "The Christian Restoration Ministries International Statements of Faith" www.crmius.org, Accessed October $15^{\text {th }}$, 2015. These statements were based on the following scriptural quotations; John 3:3,16; Romans 10:9-10; 2 Cor. 5:17-21 Rom 12:2; 2 Tim 1:7; Isaiah 26:3 Isaiah 53:4-5 Matthew 8:17; 1 Peter 2:24; Deut. 28:1-14; Malachi 3:10-11; Luke 6:38; 2 Cor. 9:6-10; 3 John 2.
} 


\section{Disaffection}

Six years after the CRMI's establishment, some of the members began to demand what Eyim-Danquah termed "their fair share of the harvest from the church." 82 This faction lamented the fact that the founder was benefitting materially from the church, and doing so at their expense. They were of the view that the pastor was hiding behind his role as religious leader to extort money from worshippers. The faction was led by individuals who played crucial roles in the organization of the church, such as, preaching and leading the congregation in the absence of the head pastor, helping in evangelism, making crucial decisions, etc., which made them feel they were as important to the church as the pastor. This was their basis for demanding the same treatment as was accorded the head pastor. Specifically, they felt they, too, had to be paid salaries.

The emerged leader, Rev. Eyim-Danquah, on the other hand, interpreted the complaints of these Ghanaian members as signs of their untrustworthiness. He felt he could not rely on them anymore. The disagreement degenerated into a schism, with the faction drifting away from the church. Some members went to form their own church while others joined went back to the existing churches in the South Florida. It is important to state that aside from the leader's view on the schism, there were other contesting voices. In a focus group discussion with some members, five out of six participants admitted that the factors that led to the break-way endure in the Church and explain the church's shrinking membership. ${ }^{83}$ Some of my discussants revealed that the

\footnotetext{
${ }^{82}$ This is the phenomenon where members who together played very significant role in the planting of the church and continue to hold certain vital position in the church demand for financial rewards for their services as the Pastor is also paid for his services.

${ }^{83}$ Adogame, The African Christian Diaspora, 117.
} 
church's spirituality leaves much to be desired. Others explained that some members leave because they feel overburdened with the financial demands the church places on them.

Some members explained that although spiritual satisfaction is their primary goal for becoming members, they sometimes expect the church to be sensitive to their parlous socio-economic conditions as immigrants. Others lamented how, despite their commitment (including financial) to the church's growth, the church does not take responsibility for the social needs of disadvantaged members. This assertion, coupled with claims of over-commercialization and commoditization of religious activities, according to the majority of members interviewed, were the main causes of the drifting away of most church members including all of the other Ghanaian founding members. ${ }^{84}$ Having had this fallout with his Ghanaian compatriots, Eyim-Danquah turned his attention to non-Ghanaian or African members.

As Ghanaian membership defected and other non-Ghanaian membership is being won to the church, people of different cultural background became members of CRMI, changing its demography. At this point, it became necessary to reshape the church's approaches to religious activities to accommodate members from other ethnicities. Rev. Eyim-Danquah described this period as the time when he made a "U turn". This means he started restructuring the church's formats and its approach to activities. These activities

\footnotetext{
${ }^{84}$ Out of 20 members interviewed on this topic, about 15 of them suggested financial demands on members is the main cause of people moving out of the church. The other 5 disagree but with the explanation that, although they are being asked to give, no one is forced to provide financial support in the church. Besides, there are times that they go to church without money yet nobody chases them out for not giving in support of the church. They added that it is their heart God wants in the church, not money. Therefore, money could not be the reason why people left the church.
} 
included the type of music used in the form of singing, ${ }^{85}$ the modes of prayer, preaching, testimonies, evangelism and many others. This marked the onset of the creative inventions that defines the church's current tradition. Rev. Eyim-Danquah explained how innovations he introduced were aimed at accommodating the needs of the new members. The changes entailed an Americanization of the tradition. Eyim-Danquah further explained some modifications he introduced into the church. They had to do with replacing the spontaneous singing of hymns in Ghanaian languages typical of Ghanaian Pentecostal churches to the formal organized singing of hymns in English. He modified his preaching style, too. He explained that, though not all members are Americans, they all participate in the American ethos, in socio-cultural, political and economic terms. It is therefore convenient to Americanize the approaches of the Christian religious activities in order to create a common denominator for all members.

Rev. Eyim-Danquah also introduced flags of several countries, which are hoisted at the welcome center of the church. When I probed further why he did this, Rev. Eyim-Danquah explained that the flags are representation of countries from which members were original citizens. He also explained that, although there are no Germans, British and or Canadians in the church, their flags were added to indicate other nations in which the Church has its extension. I also observed how a large Ghanaian and American flag stood adjacent to each other on the altar of the church auditorium. This is to further demonstrate the Ghanaianness of the church’s origins and its present American location. The change in membership also affected the pattern of the churches' organization.

\footnotetext{
${ }^{85}$ On his view about music in the church Rev. Eyim-Danquah explained that music has great bearing in defining people's culture. He therefore directed the music ministry to change their tune to follow after American contemporary music, an initiative he believed has positively affected the outlook of the church.
} 
Before the schism, leadership roles were distributed among worshipers according to their spiritual gifts. This organizational approach in most Pentecostal churches allows members to take responsibilities and play roles with little or no control by a single leader. In effect every worshiper assumes responsibilities according to their disposition of the gifts of the Holy Spirit. This phenomenon is what Asamoah-Gyadu describes as democratization of the charisma. ${ }^{86}$ However, following the schism in the church, the emerged leader adopted a new organizational style where the leadership of CRMI is centered around the Eyim-Danquah family. A closer look at the church's registration records with Florida Department of State Business Registration shows that the church currently has Rev. Eyim-Danquah, his wife, Pastor Charlotte Eyim-Danquah, and two of their sons serving as principal signatories for the church. ${ }^{87}$ This is purely a traditional Ghanaian pattern of leadership. As I will discuss in the next chapter, this is one of the innovations of this invented Ghanaian Pentecostal tradition.

Rev. Eyim-Danquah also returned to Ghana to re-organize the church he created before his departure. He established this group as a sister church of the CRMI. Both the Ghanaian Church and its American extension of the CRMI are under his leadership. He has re-structured them to operate as annexes of other. Subsequently, the suffix "International" has also been added to the name of the Ghanaian portion. The American church has since become the backbone of the Ghanaian extension, especially in terms of

\footnotetext{
86 Asamoah-Gyadu, African Charismatics: Current Developments within Independent Indigenous Pentecostalism in Ghana (Leiden: Koninklijke Brill NV, 2005), 96-97.

${ }^{87}$ Emmanuel Eyim-Danquah, "History of the Christian Restoration Ministries International” www.bizapedia.com/flCRMI-inc.html, Accessed, October 24th, 2005.
} 
the provision of funding for its infrastructural development. In addition to this Ghanaian branch, two other branches of the CRMI, one in Canada and the other in Germany have been established. Beginning as a Ghanaian migrant worshiping cell in South Florida, the CRMI has now launched a reverse mission and is expanding to different countries in the West.

\section{Conclusion}

It is clear from the history that the formation of CRMI is the product of the initiatives of ordinary migrants in South Florida. Its origin demonstrates the agency of these migrants. Also the events that led to the CRMI becoming an American church, that is, opening its doors to non-Ghanaians were linked to a faction of the migrant worshipping population breaking away from the church. In a sense this event offers another example of how actions of migrants shaped the trajectory of the Church's history. The discussion also shows that, only after the migrant Church became established and the immigrant worshipers begun to evangelize the Americans and other westerners, did the reverse mission process achieved.

The prior experience of Rev. Eyim-Danquah as a pastor gave him the advantage to transform the prayer cell into a church of his own. Consequently, the group did not invite a pastor of the established Pentecostal churches in Ghana to transform their prayer group into an institutionalized church in America. History also demonstrates some innovations the leader of the CRMI began to initiate in order to root the church in South Florida and adapt it to the ethos of the South Floridian religious landscape. This marked the beginning of the inventiveness that defines this church. In the next chapter I discuss 
into greater details the outcome of these initiatives as I focus on the tradition of the church as an invented tradition. 


\section{CHAPTER FOUR}

\section{THE CHRISTIAN RESTORATION MINISTRIES INTERNATIONAL CHURCH \\ AS AN INVENTED GHANAIAN PENTECOSTALISM}

\section{Introduction}

A theme that emerges as central to this study is the idea of religious invention. The worship tradition of the Christian Restoration Ministries International is innovative and one observes practices that seem to be improvisations. The invention process has been adapted in order to accommodate Ghanaian Charismatic religious practice to the unique needs of the members of the worshipping community in South Florida. The indigenous Ghanaian religious world views and practices which flavor Ghanaian Pentecostalism might be said to provide the foundation for this religious system, but the church later developed its own answers to a variety of questions defined by the social setting of the community. This process leaves one with the impression that the CRMI practices are an invented form of Ghanaian Pentecostalism. In analyzing the tradition from the perspective of an "invented tradition," two related questions will engage our reflection: In what context is this worship form being developed, and what elements of this worship form suggest an inventive process? In addressing these issues, I will build on the ideas of Hobsbawm and Gaurav Desai. Hobsbawn argues that when old traditions become redundant in the face of new realities it becomes necessary to create new ones. ${ }^{88}$ Building on this idea Gaurav Desai suggests that the invention of traditions does not mean creating new things out of nothing. Invention of traditions, he argues, also imply designing or

\footnotetext{
${ }^{88}$ Eric Hobsbawm, “Introduction: Inventing Traditions” in Eric Hobsbawm and Terence Ranger (Eds.) The Invention of Tradition (Cambridge: Cambridge University Press, 1983), 1.
} 
generating something (approaches and processes of doing things or models for explaining changing situations) new from the existing one or ones with or without traces of their original historic old model. ${ }^{89}$ Following the ideas of these two scholars, I argue that the social and cultural context in which the CRMI is developing, as well as the features of the worship tradition practiced in the church, suggests a creative process. The CRMI has introduced some innovations into its worship tradition in response to the needs of its American following. I will show also that as the process of inventing a new Ghanaian Charismatic religious tradition is unfolding in a North American socio-cultural context, elements of the South Floridian portion of North American Christian religious ethos, and, even its larger culture, become grafted onto the Ghanaian-originated Charismatic tradition of the community. The end product is something entirely new, neither typically Ghanaian, nor typically American.

\section{The Ghanaian Pentecostal Tradition}

Ghanaian Pentecostalism is so fluid in its forms and practices that the content and form of worship is not consistent even within Ghana. Worship forms vary by Church, geographical location, membership characteristics etc., and it makes no sense to talk about a strictly orthodox or standard Pentecostal model of worship. This is because regular religious services are not organized according to any structured liturgical order. This is one unique characteristic feature of African Pentecostal Churches. For them, the Holy Spirit is at the center of every religious activity. It is therefore not only unnecessary, but inappropriate to follow structured liturgical prints instead of relying on the Holy Spirit to order the church

\footnotetext{
${ }^{89}$ Gaurav Desai, “The Invention of Invention,” Cultural Critique24 (Spring, 1993): 119-142. 121-122.
} 
and its activities. This being the case, however, Ghanaian Pentecostalism has a definite identity, which is thought of as very Ghanaian. No matter its form or context there is always something uniquely Ghanaian about Ghanaian Pentecostal traditions, which marks it off from other forms of Pentecostal worship such as those found in other African nations, Asia, Europe, etc. These uniquely Ghanaian features in Ghanaian Pentecostalism include, for instance, the songs, sung mostly in indigenous dialects, usually Akan; the singing style, characterized by spontaneous singing; frequent interruption of events with songs; call and response; prolonged singing, accompanied with clapping of hands; dancing to a bowl to give offertory and dancing back for two or three sessions. This is done according to the days of the week on which one is born or the church's organizational patterns. ${ }^{90}$

Devotional sessions are extremely prolonged and can last over 3 hours. Narratives of witchcraft, demons, dreams and interpretation are a feature of the discourse. Even though most churches modify these practices to suit their local contexts, Pentecostal practices in Ghana generally fall within a framework. There is thus a certain common frame of reference even though there is great diversity of forms in which Ghanaian Pentecostalism is practiced. This frame of reference is by no means regarded as a standard of orthodoxy. It is sufficiently clear to give the religion an independent and special cultural identity; however, it does not give it a uniform ritual form.

\footnotetext{
${ }^{90}$ Asamoah-Gyadu, African Charismatics, 7 \& 16.
} 


\section{Invented Religious Practices}

In examining the version of the Charismatic/ Pentecostal practice of the CRMI as invented practices, we expect that the general frame of reference into which all Ghanaian Pentecostal worship falls will still be discernible. In other words, the "Ghanaianness" still prevails. But because the CRMI tradition is practiced in South Florida, a context in which it has been influenced by other, that is, American forms of religious practice, or where conditions of life have compelled the practitioners to modify their practices, it is difficult to discern the usual frame of reference in Ghanaian Pentecostal worship.

In the following description of the tradition of the CRMI, I will try to demonstrate how, even though the Church's rituals are clearly intended to fall within the general framework of Pentecostalism, the form in which worship and Church life is organized reflects a strong American influence. It could be suggested that an “Americanized" or "Western" worship system characterizes the recreated version of Ghanaian Pentecostalism practiced in this church. The resultant worship system might be described as an intricate blending of traditional Ghanaian and American Pentecostal forms of worship. In the section that follows I discuss how the indigenous Ghanaian religious world view provides the foundation for the CRMI.

As Christian worshippers, the Ghanaian lay immigrants, who created the cell that would develop into the CRMI, carried their indigenous Christian religious practices and worldviews along when they migrated. It is an obvious illustration of Afe Adogame's assertion about the relationship between religion and migration. For him, the mobility of 
religion and religious worldviews are a product of human mobility. ${ }^{91}$ This phenomenon, therefore, makes migration a channel for the transfer of Ghanaian Christian religion and worldviews into South Florida.

One of the signs of the enduring influence of indigenous Ghanaian Pentecostal religiosity in the CRMI is the way in which religious understandings seem to pervade the everyday endeavors of CRMI members. During my participation in the various religious activities, I observed that church worshipers enlisted rituals, or the help of the pastor, in addressing all kinds of issues. They would also explain every happening in their lives in terms of the CRMI's beliefs, which are heavily inflected with the indigenous Ghanaian religious worldview. Every now and then a member would come, seeking spiritual intervention in overcoming an existential problem. These include success in job interviews, help paying back loans and mortgages, the pursuit of protection against demonic attacks, healing from chronic diseases, and deliverance from different kinds of addictions. In my view, these happenings show the extent to which the Ghanaian indigenous religious worldview about the inseparable nature of religion and other aspects of life, is gaining acceptance among the American worshippers and other ethnicities who worship at CRMI. It is important to state that, although this religious worldview is common to some indigenous American churches, the emphasis and the frequent at which both the leader and worshipers engage in most religious activities depicts them as more African than not.

${ }^{91}$ Afe Adogame, "Towards Christian Disneyland: Negotiating Space and Identity in New African Religious Diaspora” in Abdoulaye Kane and Todd H. Leedy (eds), African Migrations: Patterns and Perspectives (Indianapolis: Indiana University Press, 2013), 175. 
Certainly, there are people from the Caribbean Islands, India, and Latin America where this world view is prevalent and it is not surprising that they would share in it. But it is not typical in American culture for individuals to resort to the use of religion in resolving all kinds of problems or in explaining every aspect of their lives. According to the Senior Pastor, apart from those who publicly ask for prayer requests during church services, some seek spiritual consultation with him during his counselling sessions. Testimonies of worshippers during worship also reflect how Ghanaian indigenous Pentecostal religious beliefs color their understandings of everyday events. As John S. Mbiti observed about the African society, religion pervades every component of their lives and the African by nature is notoriously religious. ${ }^{92}$ This notoriety, which is reflected in how religion is an integral part of all other aspects of human endeavors has been brought to the USA and has since found acceptance and expression among members of CRMI who are Americans, Jamaicans, Caribbean, Indians, Nicaraguans, Bahamians and Haitians.

\section{Periodic Prayer Sessions}

As seen from the previous chapter, CRMI, as it is called now, was started by three families who met weekly to pray based on the participants' religious beliefs and experiences before and during their migration processes. Their coming together to pray was also trigged by what they described as their dissatisfaction with the American religious ethos. As a result, prayers and worship activities during this beginning stage were centered on the beliefs and practices they came with from Ghana. Responding to my

92 J. S. Mbiti, African Religions and Philosophy (Ibadan: Heinemann Educational Books, 1990), 1. 
probe about the details of religious activities during their meetings, Rev. Eyim-Danquah responded. "Our main activities through 1999 were praying and singing worship songs. At the beginning, we encouraged all of us to lead during the prayer time, and at random, we usually called one person to lead during the prayers. Later, we decided that leading the prayers should be done on rotation basis among the three families. At this stage we also involved our children to pray along with us." ${ }^{93}$ Rev. Eyim-Danquah added that, with time, he became the regular leader of the prayer group. Except on the occasions that he was absent, either his wife or any member of Aryee and Adu family led the prayers.

On why their prayer activities took this form, Rev. Eyim-Danquah stated that as Pentecostals they believe that so long as one is a believer, he or she qualifies to take up religious responsibility as the Holy Spirit endows him or her. This explanation reflects the notion of the "priesthood of believers," 94 which is a defining element in Ghanaian Pentecostalism. Although this theological perspective has its root in the Protestants' traditions, in the Ghanaian Christian religious context, it was practically popularized with rise of Pentecostal churches. According to Asamoah-Gyadu, Pentecostals believe in what he describes as democratization of the charisma. This is the belief system which suggests that God makes Himself accessible to every worshiper who seeks Him. Every worshipper can, therefore, function as a vessel for the Holy Spirit. In this regards, prayer must not only be led by a ritual specialist or priests, but every believer is endowed to evangelize, plant churches and lead congregations. ${ }^{95}$ This religious orientations of the Ghanaian lay

\footnotetext{
${ }^{93}$ Emmanuel Eyim-Danquah, "Interview," November 24 ${ }^{\text {th }}$, 2015, at the office of Christian Restoration Ministries International Miami, Florida.

${ }^{94} \mathrm{E}$. K. Gbordzoe, The Corporate Identity of the Global Evangelical Church (Accra: GEC Press, 2007), 14. ${ }^{95}$ Asamoah-Gyadu, African Charismatics, 96-97.
} 
immigrants further accounts for their agency to initiate religious cells; first, for satisfying their own religious needs and second, to convert others to their religious groups.

On the content of their prayers, Rev. Eyim-Danquah mentioned many subject matters that became the focus of prayers. Pressing among these issues were requests for God's protection against any form of evil machination from the devil. Narratives about satanic forces acting to derail the lives of worshipers feature strongly in the Ghanaian Pentecostal traditions. The narrative posits that it is the wish of the devil to destroy every believer. The devil also teams up with local witches in wreaking havoc on peoples' lives. Combating the activities of the devil and his agents necessitates continuous praying and engagement in other religious rituals. The families also pray for the wellbeing of their immediate families back in Ghana. Sometimes the prayer was for God to prevent the devil from using family members as agents of harm. This belief that some family members have satanic/demonic spirits that have the potential to inflict harm on believers is grounded in the Ghanaian Pentecostal narratives about demonic doorways. Opoku Onyina describes demonic doorways as anything, including objects, personal habits, accidents, intimate relationship with people inhabiting demonic spirits, ancestral worship and curses, that exposes individuals to demonic manipulation, attacks or possession. ${ }^{96}$

This Ghanaian Pentecostal Christian religious worldview found expression in the focus of the prayer sessions of the cell. This worldview also provided an important reason for prayers made for families living in Ghana. The three families also prayed for

\footnotetext{
${ }^{96}$ Opoku Onyina, "Deliverance as a Way of Confronting Witchcraft in Modern Africa: Ghana as a Case History," Cyberjournal For Pentecostal-Charismatic Research, http://www.pctii.org/cyberj/index.html, Accessed, June 20 2015.
} 
members who concurrently had bad dream experiences. Rev. Eyim-Danquah explained that, during their meeting some members narrate their dream experiences. If the dream was a sign of an impending disaster, the cell would pray for God's intervention either for the individual (dreamer) or the whole group and their families back home. The Senior Pastor clarified that dreams are God's direct way of revealing future events. Dreams also reveal spiritual attacks. Dreams featured prominently in the cell's worship tradition. The cell also prayed about issues that affected them in their day today lives South Florida.

As settling immigrants, the members were also faced with existential challenges such as securing their legal residential papers as well as decent employment. Mr. Aryee, a founding member emphasized how states “prayer was our source of protection and good health.”97 He was clear in explaining that the costly healthcare system of South Florida was a threat to their survival. As a result, prayer for good health always took center stage during their meetings. Prayer was a ritual that defined this worshipping cell. Its usage as a weapon against Satan/demons was informed by indigenous Ghanaian Pentecostal meanings. Some of the Ghanaian indigenous Pentecostal traditions that occasioned the origin and characterizes the church’s activities at its beginning stages still persist, even after attempts to Americanize the CRMI. This will be seen in the religious beliefs and practices of the church as I have discussed them in this chapter.

\section{Intercessory Prayers/Prayer Meeting}

The periodic prayer sessions that marked the beginning of CRMI continue to define its tradition. The church holds prayer services every Monday, Tuesday and Thursday

\footnotetext{
${ }^{97}$ Mr. Aryee, “Interview,” December 8, 2015, Through Phone call.
} 
evenings between the hours of 6:00 and 7:00. During my fieldwork, I participated in many of these sessions. The prayer service held on Tuesday is called Intercessory Prayer Hour. These prayer sessions were all led, on rotational basis, by the senior Pastor's three sons who are currently undergoing training as pastors of the church. During the service the leaders would identify different challenges, and the congregation would pray for the elimination of these problems. The challenges range from specific needs of individual church members to general problems that affect the larger society. Individual members pray for health, financial success (in the areas of ability to pay loans and mortgages), well-paid job opportunities, good marital relationships, and ability to give birth (refers to as gift of the womb) and other challenges. The attendants at the evening prayer services also prayed for the larger society and the wellbeing of the communities in which they live and work.

Among the general issues they direct prayers at, are the rapid growth of the church and its institutions, peace in America and the general socio-economic and political environments in which people live. Prayers are also made to God for protection against criminal activities in South Florida and all over the world. These prayers emphasize the need for peace in countries whose citizens are represented in the church. Before the leaders bring the prayer meeting to a close, they always ask if anyone among the worshipers has a special request that has not been mentioned and prayed for. This time also affords the worshiper the opportunity to give testimonies about how past prayers have been answered. As I participated in the prayer sessions, I noticed that the most recurring foci of prayers were wealth, protection against spiritual attacks, and the general wellbeing of individual worshipers and the society at large. These emphasis shows how 
seeking God's help in attaining material wealth, and in fighting against spiritual attacks continues to be central to the current worshippers as it was to the originators of the cell that marked the early beginnings of the church. This tradition of praying, where worshipers concentrate on attacking demonic spirits working against them was brought to America from Ghana and has been maintained as a foundational aspect of the CRMI's tradition. However, improvisations had to be introduced to accommodate the unique situations of life in South Florida. The CRMI's Prophetic Prayer Conference program offers us an opportunity to explore these innovations.

\section{Prophetic Prayer Conference}

The CRMI' prophetic prayer conference is an online prayer meeting. The Prophetic prayer conference is a 30-minute prayer session held every Sunday morning at 6:00. am On Sunday morning's participants dial in to a given conference call code to participate in the online prayer session. During the prayer period the phones are muted to all participants except the voice of the leader who calls the various prayer topics and asks participants to pray on the mentioned topic along with him or her. Throughout this research period, I participated in all the prophetic prayer conferences, which were generally led by Mrs. Trekiece Eyim-Danquah, wife of the Minister/Pastor Ralph EyimDanquah. Sometimes the Senior Pastor also leads the prophetic prayer conferences. Though at the Monday, Tuesday and Thursday intercessory prayer sessions, prayers target problems that affect members, the online prayer service did not afford participants the opportunity to request prayers for their individual needs. The Sunday morning prayer 
always ended with the participants saying a prayer called "Sharing the Grace" during which the phone line was unmuted.

When I asked Rev. Emmanuel Eyim-Danquah about how and why the prophetic prayer conference was incorporated into the church’s activities, he replied;

The prophetic prayer conference is one of the programs we designed following our initiative to Americanize the church. We have realized that the many American people in South Florida don't have time to attend the in-person intercessory prayers organized during the week. Moreover, they don't want to stay in Sunday church services for very long. We therefore introduced the prophetic prayer conference to create an avenue for such members to pray in the comfort of their homes. ${ }^{98}$

The online prayer session, according to Rev. Eyim-Danquah, has also helped the church cut down on the time it uses for the Sunday church services. This situation represents a sharp contrast to the tradition of CRMI's sister church in Ghana where the entire congregation is always physically present for devotional services and the worship lasts between three to six hours. The "U turn”, which according to the Senior Pastor marked the change from African approaches to church activities to American styles, in my view, is also reflected in the use of resources in the American setting to facilitate participation in religious activities. ${ }^{99}$ In the face of members' inability to actively and regularly participate in religious programs, the church ingeniously took advantage of electronic media and reached out to members. Through the use of the phone, members can participate in worship without being physically present. Messages from the church

\footnotetext{
${ }^{98}$ Emmanuel Eyim-Danquah, "Interview," November 24 $4^{\text {th }}$, 2015, at the office of Christian Restoration Ministries International Miami, Florida.

99 Birgit Meyer, "Pentecostalism and Globalisation,” in Allan Anderson et. al.(eds.), Studying Global Pentecostalism: Theories and Methods (University of California Press, Berkeley, 2010), 119-120.
} 
inviting members to join in the worship and indicating the time are always displayed on the web pages of the church.

In my online search about the church, I also discovered that videos of sermons delivered by the Pastor were also uploaded for the general public. ${ }^{100}$ The use of media (print and electronic) further shed light on the extent to which Charismatic Churches from Africa are able to contextualize their religious ethos in changing socio-cultural, political and economic settings. ${ }^{101}$ This ability to contextualize, according to most mission scholars, is one characteristic aspect contributing to the rapid growth of Charismatic Churches in Ghana, Africa and beyond. ${ }^{102}$ The impact service and solution hour are other innovations introduced into this original Ghanaian Pentecostal tradition so that it can meet the needs of non-Ghanaian elements and also adapt to conditions of life in the USA.

\section{Impact Service and Solution Hour (Healing and Deliverance Program)}

The church has also introduced healing/deliverance, prayer and ministration programs known as "impact service" and "solution hour." Both are monthly prayer sessions introduced into the church to provide spiritual support to members and people with special spiritual problems. During these times persons who seek spiritual solutions to their existential needs are attended to through holistic prayer processes known as

\footnotetext{
${ }^{100}$ Sermon Delivered by Rev. Emmanuel Eyim-Danquah, http://www.crmius.org/sermon/overcoming-theenemy/, Accessed October $16^{\text {th }}, 2015$.

101 Afe Adogame, "Traversing the United Kingdom of God," in Ludwig and Asamoah-Gyadu (eds.) African Christian Presence in the West: New Immigrant Congregations and Transnational Networks in the North America and Europe (Ibadan: Africa World Press, 2011), 73.

${ }^{102}$ Anderson, An Introduction to Pentecostalism, 122.
} 
ministration. In Ghana, healing and deliverance ritual is a routine feature of worship. Because the duration of worship is very long, two or three hours can be devoted to these activities. In South Florida where worshippers must divide their time between working, taking care of their children, engaging in domestic chores, and other activities, their participation in such long deliverance services cannot be guaranteed. This is why the CRMI has created the impact service and solution hour. While "impact service" is held on the first Friday of every month, "solution hour" is scheduled on the last Sunday of every month. Both programs are organized between the hours of 19:00 and 20:30. The two prayer services are much alike in term of activities but the approaches seem different. During the times I participated in both services they followed the procedures as I describe below.

At exactly 19:00 at the "impact service," Minister Emmanuel Jr. started the program with an opening prayer after which he invited the praise and worship team to lead in song ministration. Under the leadership of Pastor Ralph Eyim-Danquah, the praise and worship team, made up of four gentlemen and four ladies sang songs of adoration and exhortation accompanied with musical instruments. The praise and worship lasted for about 15 minutes, after which Minister Ralph introduced the Senior Pastor to deliver the message of the day. Preaching on the theme "wait upon the Lord," Rev. Eyim-Danquah chose his scripture reading from John 5:1-14, which recounts how a man who suffered for thirty-eight years got healed after he met Jesus. He used this passage to admonish the worshipers to have faith in God. He also entreated them to believe that regardless of the gravity of their problems and no matter how long it has taken, their encounter with Jesus during the "impact service," will bring the problems to an end. 
When I asked Rev. Eyim-Danquah about the significance of the message and the order in which the program was followed, he answered saying, "I have been inspired to organize the program in this way in order to ensure that it has changing effect on the lives of the people." He added that "the main purpose for the service is to minister to people through prayers, anointing and laying of hands on worshipers for healing, deliverance and other forms of spiritual and material breakthroughs. However we have arranged to have song ministration and preaching the word of God in order to prepare the believers to be in expectation for their own miracles." ${ }^{103}$ At the end of the preaching, which took about 30 minutes, the Senior Pastor led the worshipers through a loud congregational prayer. He identified different issues, mostly problems, that worshipers prayed to eliminate. The prayer was noisy. When the noise would subside, another prayer would begin. After this came the Altar call. This is the practice of inviting people to come up to the front to be prayed for. The act of inviting the people by mentioning the problems they have come to be prayed for, according to Rev. Eyim-Danquah is known as "using the word of knowledge.”104 He explained that although none of the people who came out spoke to him about their challenges, he perceived that some members among the congregation were having chronic bodily malfunctioning.

While the clients ${ }^{105}$ stood in front of the congregation waiting for solutions to their problems, the pastor ministered to them in different ways. He laid hands on some

\footnotetext{
103 Emmanuel Eyim-Danquah, “Interview,” November 24 ${ }^{\text {th }}, 2015$, at the office of Christian Restoration Ministries International Miami, Florida.

104 Yohanes K. Ahiabu, "Healing and Deliverance in Church Growth: The Case of the Global Evangelical Church from 1991 - 2011,” MPhil Thesis (University of Ghana, Legon, 2013), 86-87.

105 "Clients" as used in this context refer to people, both members and non-members of the church who seek one kind of spiritual solutions to their problems through the church and its ministers.
} 
and prayed for others. He also dipped his fingers in a plate of olive oil, smeared the oil on the forehead of others, and prayed for their healing. ${ }^{106}$ In some cases the pastor asked the clients to repeat certain incantations after him, to affect their healing. The act of smearing the oil on the client, according to Rev. Eyim-Danquah, is termed anointing for healing. ${ }^{107}$ The process of ministering to the clients to induce healing and other solutions to their problems is collectively referred to as "using words of wisdom." ${ }^{108}$ As the Pastor was ministering to the clients, the praise and worship team sang hymns in the background. The "prayer warriors" 109 were also engaged in intense prayers meant to invite the inworking of the Holy Spirit. This is because it is believed that that the presence of the Holy Sprits makes the ministration process successful. At some point in time the pastor asked the entire congregation to stretch their hands towards the clients and to pray for their healing and deliverance. This symbolizes the collective participation of all worshippers in the provision of spiritual solution to the problems. I also observed that, as the pastor would lay his hands on some of the clients, they would fall backwards, into the waiting arms of two able men (ushers) who would hold them and lay them on the floor.

After all the clients had been attended to, the pastor looked around the room and asked the congregation whether anyone has a testimony to share. A man and a woman narrated how they had miraculously received answers to their problems after they were "ministered” to during the previous month’s "impact service." The woman, Miss Grace,

\footnotetext{
${ }^{106}$ Asamoah-Gyadu, African Charismatics, 188.

107 Rev. Eyim-Danquah explained that the use of oil is the symbolism of the Holy Spirit. In effect, the people are being healed through the power an impartation of the Holy Spirit.

${ }^{108}$ Ahiabu, "Healing and Deliverance in Church Growth,” 86-87.

109 The prayer warriors are members of the prayer ministry who assist the pastor in prayer activities.
} 
talked about how she was healed from a knee pain she had, that defied medical treatment. The man, Zuity, testified about how he miraculously found money to pay his mortgage to prevent the bank from foreclosing on it. Another worshiper, a Ghanaian, also gave testimony about how God saved her from being implicated in the case of a patient's problem at the health facility where she works. According to Miss Meleme, she had a dream in which her grandmother who had died many years past died again in Ghana. Upon her consultation with the Pastor, he told her to fast and pray. Three days later, her colleague was laid off on the ground of negligence in attending to a patient. For Meleme, God used the dream and guidance of the pastor to save her. This is because she could have been a victim of the laid off. Testimony after testimony described what God had done to solve worshippers’ problems followed during the service.

The "solution hour" is similar to the "impact service" in terms of procedure. The main difference between the two events is that the prayer session during the impact service is more intense, the duration is longer, and more time is devoted to individual worshipers and clients who need special prayers and ministration.

The "impact service" also involves congregational prayers accompanied with emotional shouting, hand clapping, swaying of the body and spontaneous utterances of incomprehensible words understood as speaking in tongues. In some cases, clients are scheduled for counselling with the Senior Pastor after the impact service. When I asked Rev. Eyim-Danquah about the significance of the counselling to the prayer sessions, he explained that "some of the clients have certain challenges they would not want to speak about in front of the congregation. The counselling session enabled offered the pastor and the client the opportunity to deal with the matter privately and for the pastor to offer the 
client detailed and specific spiritual guidance." 110 The "solution hour" is a shorter ritual session. Pastors did not minister to worshipers on individual basis. The clients were not invited though altar calls. Rather, they were asked to stand, raise their hands or place their hands on a part of their body that was afflicted. Then they were prayed for.

\section{Sunday Devotional Service}

As mentioned in the last chapter, the CRMI holds two devotional sessions every Sunday. The first service begins at 7:30 am and ends at 9:30 am. The second service is also a two-hour session, from 10:00 am to 12:00 noon. Rev. Eyim-Danquah described how he deliberately structured the worship to ensure that its purposes in the church are achieved. He mentioned that although the church is of Ghanaian charismatic orientation, his approaches to worship are a little different from what is usually done in other churches in Ghana. His devotional sessions are shorter. Except for some details and a few individual activities, such as preaching and song ministration, ordinary Sunday church services are structured in the same pattern as the "impact service" and "solution hour," which I have discussed earlier. I shall therefore concentrate on the exceptional elements associated with Sunday devotional services. I begin with an account of my personal experience of the worship culture of the CRMI.

On November 8th, 2015, I arrived at the CRMI premises at 8:50 am. A young man wearing ushers' tag standing at the outer door shook my hand and said to me "Hello my name is Chris, welcome to Christian Restoration Ministries International.” "My name

110 Emmanuel Eyim-Danquah, "Interview," November 24 ${ }^{\text {th }}$, 2015, at the office of Christian Restoration Ministries International Miami, Florida. 
is Raymond, thank you,” I replied. He led me through the inner door into the church auditorium where he guided me to sit. At 5 minutes to 9:00 am, I saw four young men and four young ladies at the altar of the auditorium fixing musical instruments and testing microphones. At 9:00 am when the auditorium was about half full, a man, about thirty years stepped out of those standing on the altar and said "You are all welcome to Christian Restoration Ministries International, please let's stand up and start the church service." He said a short word of prayer and said "let's all sing as we worship the Lord together.” The whole congregation sang for about 5 minutes, along with the choir who were backed by sounds of musical instruments such as guitars and a keyboard. Before the singing ended, a young man carrying an iPad, walked in with the Senior Pastor who mounted the altar and briefed the church about the day's program. He also used the opportunity to introduce me to the congregation. Then he said; "Let's have the announcement from media ministry.”

The day’s announcements were recorded on video by Minister Emmanuel EyimDanquah Jr. who also worked as a member of the media ministry. The video recording was displayed on two thirty-two-inch LCD monitors that were fixed at the top left and right corners of the auditorium. Before the announcements the church's vision statement was displayed on the TV screen. It read "To glorify God, by leading people to know Jesus and the benefits of His family; equipping them as true disciples to serve both in the Church and in the world. Amen”111 The congregation read it aloud. Minister Emmanuel Eyim-Danquah Jr said the collective recitation of the vision statement was intended to

\footnotetext{
111 Eyim-Danquah, Emmanuel "The Christian Restoration Ministries International Vision Statements" www.crmius.org, Accessed October 15 ${ }^{\text {th }}, 2015$.
} 
remind members of their obligations as Christians, and to encourage them to fulfil them in their daily Christian lives.”112 The recorded video of the announcements was played. The announcement consisted of reminders to members of weekly religious activities. These included the Monday, Tuesday, and Thursday prayers, and the dates slated for the Impact Service and the Solution Hour. Other special upcoming events, such as the International Day celebration, and programs lined-up for the end of 2015, including Christmas revivals and the December $31^{\text {st }}$ Cross-Over church service, were announced. The video ended with a request to members who had birthdays in the week, to stand up. Three persons stood up, and the praise and worship team led the whole congregation to sing "Happy Birthday to you," and wish them God's blessing. This was a show of support for these individual members. But it also reflects the influence of a South Floridian or American birthday tradition.

In Ghana, birthdays are viewed as private or family affairs and many people do not announce their birthdays in public. Also announcements are often read in Ghanaian Pentecostal/Charismatic traditions. They are not videotaped and played to worshippers. There is an official responsible for reading announcements. Not only is CRMI's use of TV recordings to announce events to worshippers another innovation inspired by similar practices in churches in South Florida, it is also a pragmatic approach designed to save time and labor. Many worshippers had to leave for work, or to engage in other important activities after devotional services, and needed time for these. The CRMI demonstrates sensitivity to this need by coming up with time-saving approaches to worship. The praise

${ }^{112}$ Emmanuel Eyin-Danquah Jr., “Interview”, December 18 ${ }^{\text {th }}, 2015$. 
and worship session, which lasted for another 15 minutes, was performed by the whole congregation. The church choir and the praise and worship team led this session. Worshippers moved towards the altar for this purpose. The praise and worship session is vibrant and lively. The lead singer would introduce a song and members would join in. The songs were uplifting and worshippers danced throughout in typical Ghanaian Pentecostal fashion.

After the praise and worship, all worshipers except Minister/Pastor Ralph Eyim-Danquah left the altar for their seats. Pastor Ralph introduced the preacher for the day when he said; "today we have a special message from the Lord and it will be delivered by no other person than our Rev. Dr. Emmanuel Eyim-Danquah.” The mentioning of the name was greeted by cheers and the clapping of hands in accompaniment with some interlude from the musical instrumentalists.

Rev. Dr. Eyim-Danquah mounted the altar with the young man carrying his iPad and face towel. The young man placed the iPad on the pulpit. Notes on the sermon for the day had been typewritten and stored on the iPad. He preached on the theme "Inevitability of faith in believers' lives.” He started by saying; "Today I want to share with you, certain areas of life where you cannot take away faith.” He linked having faith to the financial success of members. He entreated them to act on their faith in order to become financially successful. While delivering the sermon, Rev. Eyim-Danquah would occasionally interject with a prophetic declaration directed to a specific person among the worshipers [who he names or points to] or to the entire congregation. This was followed by the offertory. Finally, an announcement was made for "new comers" to stand up. Four 
persons (three ladies and a man) stood up and were welcomed with cheers and hand clapping. The pastor asked them; "how did you hear about the church or who invited you?” Surprisingly, they all mentioned Madam Xoese, a woman who was healed of a heart problem through the Pastor's prayers. The new comers were asked to complete a first comer's form which entailed offering information by which they may be contacted. The Sunday Church Service ended with us sharing the grace, a form of benediction which we all recited.

\section{Preaching, Prophesying and Offering Money}

I have identified preaching, prophesying, and money offering to be very central to the religious ritual practices of CRMI in Miami. Although these three phenomena are separate activities, their interrelatedness in the CRMI warrants their discussion as an integrated whole process. Preaching in the CRMI follows an exegetical approach whereby biblical scriptures are applied to the practical day-to-day lives of believers. I have observed that during preaching, not only does the preacher provide directions on how audiences must apply the lessons in their lives, he also introduces prophetic declarations intermittently. Easton's Bible Dictionary defines prophecy as "miracle of knowledge, a declaration or description or representation of something future, beyond the power of human sagacity to foresee, discern, or conjecture."113

In the Pentecostal traditions of Ghana, a prophetic declaration is a form of prayer. In a typical prayer in the Ghanaian Pentecostal tradition, a worshiper implores God or the

\footnotetext{
113“Prophecy,” Easton’s Bible Dictionary, (International Bible Translators Inc., 1988), (Electronic version).
} 
Holy Spirit or Jesus [through words he or she speaks,] to bring about a change in a situation, and relies on this object's benevolence for the results. In a prophetic declaration the worshipper depends not only on God or Jesus or the Holy Spirit but also on the power of the words spoken, to bring about what is desired. The worshipper sees himself or herself as an active agent in the manifestation of his or her expressed desires, not a passive recipient of blessings. As one pastor explained to me, "When you make a declaration before God, you say what you want and believe that it is only a matter of time until what you have spoken in the spirit realm manifests itself in the natural.” When worshippers are making declarations, they, first, identify a problem they are experiencing, describe sought after solution, and find the proper scriptural context in which their situation can be located. For example, a person dealing with a sickness would, in a declaration, state that he is healed of the sickness according to the teachings of a scripture (Father in the name of Jesus, I decree and declare that I am now healed according to your word. I confess according to Isaiah 53:5 that by your stripes I am already healed.) The declaration has the effect of shifting the malady to health. These are performative utterances; by saying words, one is bringing about what is said. Worshippers of neo-Pentecostal traditions often make their own declarations. But prophets can make declarations on behalf of worshippers, asking them to "receive" the declarations. Sometimes, the prophet simply leads the congregation in making declarations. He or she reads the declarations out aloud and the congregation repeats the words after him or her. Declarations are a defining feature of the CRMI. The preaching ended with altar calls, accompanied with prayers and ministrations. 
In its usage during church services the pastor would, for instance, say to the congregation, "I prophesy to you that you shall not die prematurely!!!” "I prophesy that you shall see your financial breakthrough before the end of this year." And the congregation responded with a loud voice, “Hallelujah!!! Amen!!!” or "I receive it.” In other instances, the pastor would recite certain biblical statements and ask worshipers to confer it on themselves. This prophetic phenomenon seems to be a direct transplanting of Ghanaian Pentecostal and Charismatic practice known in some local languages as nyagblıdi or Nkomshyie. According to Omenyo, the contemporary prophets are characterized by a practice commonly called 'prophetic guidance' or akwankyere, a practice that tends to explain a person's knotty circumstances and prescribe keys to solutions. It is believed that sometimes the prophets give them prophecies which satisfy them." 114 This is one way in which the Ghanaian-founded church is rooting Ghanaian and African Pentecostal traditions in America.

During one of my visits, the preacher preached on the theme "overcoming satanic manipulations." In the process, the pastor asked us to declare after him "I shall not die, but live, and declare the works of the LORD” (Psalm 118:17). We also recite statements as "I have soaked myself in the blood of Jesus... no demon can touch me." The pastor even asked us to make such declaration about people sitting next to us. In fact, the applications of prophecy are so diverse that it very much demonstrates the dynamism and flexibility with which the Charismatic churches approach their religious activities. ${ }^{115}$ While the prophetic phenomenon seems inseparable from preaching in the CRMI, money

\footnotetext{
${ }^{114}$ Cephas N. Omenyo, "Man of God Prophesy Unto Me: The Prophetic Phenomenon in African Christianity" Studies in World Christianity. Volume 17, Page (2011), 30-49.

${ }^{115}$ Anderson, An Introduction to Pentecostalism, 122.
} 
offering appears to have become an obvious component of the two. Although money offering may not be considered as religious ritual, the act is at the heart of almost every religious activity that took place during my research.

Except for the "intercessory prayer," we gave money offering during every religious service we attended. In all the religious activities in which I participated, about $95 \%$ of the sermons delivered were geared, at least in part, towards worshipers' realizing their existential needs and becoming prosperous. The sermons reflect this emphasis on prosperity. Sermons I have listened to include, "Ten reasons we should suffer for God,” "Responding to the Great Commission," "Faith for your daily walk.” The underlying theme in these sermons was how worshippers can succeed by following God's words. According to Rev. Eyim-Danquah, this theme is in keeping with the church's vision statement, which emphasizes enabling positive transformations in every facet of worshippers.

I have also observed how, in most of the sermons preached, giving offerings, especially money offerings, is not only stressed, but almost always justified religiously. The notion that making money offerings to the church is a sacred duty of worshippers is another recurring theme in CRMI's sermons. Some preachers also stress how money offerings guarantee answers to worshippers' prayers. This discourse on giving money to the church is a defining element of the CRMI's tradition. A related narrative emphasizes the need for members to practice seed sowing. In Ghanaian Charismatic Christian expression, this is the act of offering money and other resources in exchange for answers to one's prayers, or blessings from God. One can sow a seed, that is, make a money 
offering in support of a church's development project, or as a donation to the church leader. Members are encouraged to sow not any ordinary seeds but "good and viable seeds" that will germinate and bear good fruit in the form of the members prospering in their lives' endeavors. ${ }^{116}$ Some members consider the making of money offerings or donations to the Church a sine qua non for the realization of their prophecies.

In a focus group discussion, some informants claimed to have received answers to their requests in diverse ways only after they donated money to the Church. But many informants lamented what they described as the CRMI's money-mindedness. Some members talked about how others had left the church because they were overburdened by the Church's excessive demands on them to donate money. During one of my visits, the senior Pastor reacted to members' complaints by explaining how worshipers must not feel pushed to donate money, but to give as much as they can voluntarily and from their "hearts." He further cautioned that they should not miss church gatherings because of the constant demands on them to donate money. "God desires their hearts, not their money," the pastor encouraged.

The money-centered discourse and related practices of the CRMI reflect the strong influence of the prosperity gospel on its tradition. According to the prosperity narrative, applying the Bibles’ teachings inexorably, and strictly following spiritual laws guarantees material prosperity of believers. God did not create anyone to be poor, the narrative holds. Poverty is the work of the devil. In Ghana, where many of the followers of Charismatic Churches are facing difficult economic times, are ambitious and are

\footnotetext{
${ }^{116}$ Asamoah-Gyadu, African Charismatics, 212.
} 
striving hard to make it, the leaders of the churches emphasize how donating money in church generously, and sponsoring church projects, speeds up worshippers' prosperity. ${ }^{117}$ This would seem to be an income-generating strategy of these churches. The CRMI has extended this practice to South Florida. It, however, does not stand out in this respect because there are many other South Floridian Christian Churches that also subscribe to the prosperity narrative. Arguably, the Ghanaian Charismatic Church emphasis on prosperity was largely influenced by the American prosperity gospel movement in the late seventies eighties and nineties. It is not clear, however, whether these churches are as money minded as some worshippers of CRMI describe their church.

Even though the emphasis on money, typical of Ghanaian Charismatic Churches, endures in the CRMI's tradition, its offertory system is highly Americanized. A white bag is passed around for worshippers to deposit their money offerings during offertory. In addition, money offerings can be made through the electronic swiping of debit or credit cards, so that worshippers who do not have cash can still make donations. Music is provided by the praise and worship team during offertory. Conspicuously absent is the common Ghanaian Pentecostal offertory system whereby worshippers dance to the offertory box and deposit their donations and dance back to their seats.

Also absent is the Kofi and Ama offertory system, a Ghanaian innovation whereby worshippers make offerings of money according to the day of the week on which they were born. In the traditions of most Ghanaian ethnic groups, people are named according to the day of the week on which they were born. Among the Ashanti

\footnotetext{
${ }^{117}$ Asamoah-Gyadu, African Charismatics, 208.
} 
ethnic group, this day name reflects the day of the week on which God created the person's soul. Christian Churches make use of this Ghanaian tradition during offertory. When a day is mentioned, all worshippers who were born on that day will dance to the offertory box and put in their donations. The contributions of worshipers born on each day of the week will then be tallied. Those whose donations are highest are declared winners. This ethos of competition helps churches in their efforts to raise money because often worshippers born on specific days try to "out-donate" others. Because there is no day of the week naming tradition in the USA it would make no sense to introduce this typically Ghanaian offertory system into the offertory traditions of the USA. This explains why the CRMI has not adopted this crucial fund-raising mechanism, in spite of its money-mindedness. This is a crucial example of how the CRMI sometimes deemphasizes some cultural practices in order to fit into the ethos of religious practice in South Florida or the USA.

\section{Praise and Worship}

As I indicated in the beginning of this chapter, the praise and worship session is an integral part of every church service. The praise and worship team is composed of twelve members. Their leader is Pastor Ralph Eyim-Danquah. In most cases the group performs songs of worship, adoration and praise at the start of worship, before sermons are delivered, and after preaching. Although the general congregation participates in the singing of songs, it is the responsibility of the praise and worship group to make worship in the church very vibrant and attractive to members, especially first time visitors. Indeed, some respondents linked the appeal the Church held for them to the music. Three of my 
friends who drove me to the church also noticed something distinct about the music. They said it was very uplifting. Isis, one of my friends, for instance, said "I would love to join this church because it is very vibrant, especially the music." 118 Throughout my visits I noticed that although all the members of the team were of African descent, the songs were very American. The lyrics did not show any sign of African themes that had been contextualized to fit the American socio-cultural setting of the Church. The rhythms also follow American popular music style. When I commented on the Americanness of the singing and the music, the head Pastor offered me a lecture on the history of music in the CRMI's tradition:

At the formative period of the church (in the first six years of its formation) the choir performed with local Ghana songs that were African in rhythm and lyrics. However, when I took the "U" turn decision, the music which is a major form of our religious expression also has to change. I therefore sponsored the choir's trip to Texas for a conference on three different occasions, an initiative that exposed them to the American Charismatic experience and also afforded them the opportunity to bring what they had learnt to our church; and it was successful. ${ }^{119}$

Thus in order to present music in the church in a way that would accommodate the cultural needs of worshippers, the Pastor introduced innovations into the Church's music tradition. This is an invention of African Christian musical expression to suit the American religious and socio-cultural context. Not all African Churches in the USA follow this pattern, though. Many of them have found creative ways of blending African and American music styles.

In one of my discussions with five members of the praise and worship team, the group expressed how difficult it was when they had to, all of a sudden; re-orient their

\footnotetext{
${ }^{118}$ Isis Elis (A first time worshiper at CRMI), “Discussion” November 24 ${ }^{\text {th }}$, 2015, at Christian Restoration Ministries International Church Premises.

${ }^{119}$ Emmanuel Eyim-Danquah, "Interview," November 24 ${ }^{\text {th }}, 2015$, at the office of Christian Restoration Ministries International Miami, Florida.
} 
performance style to adapt to the changes the Church was going through, especially in terms of its general approaches to religious activities. For them, the problem was not only that they had to become accustomed to the use of modern musical instruments, but was also the countless hours they spent rehearsing, as they needed to be prepared to perform in church on every Sunday. Ministers Emmanuel Jr. and Enoch, for instance, added that they had no knowledge about musical instruments before coming to the USA, but with the turn of events, they had to practice on their own to attain their present level of mastery over the keyboard and the guitar. The group also agreed with other respondents that their role in the church is crucial because music is one of the factors that attracts visitors to the Church and also keeps them in. Pastor Ralph, for his part, stated that he is under constant pressure to update his knowledge of contemporary flows or trends in American gospel music and the other kinds of music American Charismatic churches are performing. He said this was important because the CRMI's tradition has to be abreast with contemporary trends in the USA. This is a further indication of the continuous innovative processes that has come to characterize the tradition of the CRMI.

\section{Outreach to Society}

American society expects religious institutions to be responsive to the needs of society. Religious institutions, in turn, demonstrate their responsiveness through many outreach activities. Having come to understand this expectation, the Christian Restoration Ministries International also engages in other social activities to complement its ritual processes. The "benevolence ministry" is responsible for these activities. These other services are generally tailored towards meeting the church's social responsibilities. 
Common among the activities that constitute these social responsibilities are providing food for needy members and non-members of the church, providing members with financial support to pay their rents and in settling hospital bills, educating members so that they adopt healthier lifestyles, and creating awareness about security issues in American communities.

According to the Senior Pastor, the church educates newly arrived immigrants on many issues, especially those related to how to acquire their legal documents and find employment in South Florida. For him, the provision of these social services is in fulfilment of the church's vision statement; that is, to provide nurturing to people so that they can be useful to the church and the world. ${ }^{120}$ During my interviews and discussions with members of the Church, about $70 \%$ of respondents expressed their disappointment about how the church was not doing enough in its provision of social services. These respondents claimed that it is because of some discrepancies involved in the provision of social services in the church that some members had left the church: they felt left out. However, the Senior Pastor stated that the social services and the vibrant religious activities are some of the attractive programs that endear the church to people. From his perspective, some members left the church because of their lack of commitment to voluntary service to God in the church. These divergent views on provision and denial of social services point to the contesting voices in the Church.

\footnotetext{
${ }^{120}$ Eyim-Danquah, Emmanuel, "The Christian Restoration Ministries International Vision Statements" www.crmius.org, Accessed October 15 ${ }^{\text {th }}, 2015$.
} 


\section{Other Programs}

Apart from regular Christian religious services and embedded activities, the CRMI has designed programs to satisfying members’ communal needs. Since its time of broadening the scope of religious activities to embrace other nationalities other than Ghanaians and Africans, the CRMI has incorporated certain activities geared towards making the church a social space for all members. Among these programs are celebrations of "International Day" and "Shocknight". International Day is celebrated on the first Saturday of December every year. During the 2015 International Day, members were asked to prepare and bring in traditional foods from their country of origin. By the time I got to the church's premises at 4:00 pm, traditional dishes of the ten countries whose nationalities are in the church were labelled and arranged in the fellowship hall.

After the Pastor had blessed the food, a member of the organizing team announced that we could all pick and taste the food from any cultural tradition. For the next one and half hours, members ate and had social interactions with one another amidst music and dancing. For members who spoke to me about the program, its uniqueness lies with the opportunity to interact and learn something about one another's home countries. The pastor and his wife had a more theological understanding of the value of the event. They said it was a demonstration that regardless of their differences in terms of nationality and traditions they are all one people under the calling of one Master, the Lord Jesus Christ. Similar socializing activities are organized by groups such as “Youth/Aftershock, Men’s Fellowship and Women’s Fellowship and meet biweekly. While Aftershock organizes Shocknight, a youth-oriented socialization program for the youth in the church, the men's and women's fellowship groups meet regularly to 
socialize and to discuss common issues that affect them as adult men and women. These practices root the CRMI in South Florida, making it an American church.

\section{Evangelization and Recruitment Practices}

Emphasis is not placed on aggressive recruitment in many Ghanaian Pentecostal churches. It is not as if these churches do seek to attract members. They simply do not devote too much effort or other resources to recruitment. The fact is that there is always an overabundance of potential worshippers seeking forms of spiritual cover in Ghana. In the context of the drying up of sources of wealth, high unemployment, growing social inequalities, and impoverishment, survival in Ghana is increasingly tied to the capacity to access the spiritual universe for magico-religious cover. In the context of the high demand for ritual contexts that produce spiritual cover for people, many new churches attract followings the moment they become publicly visible. Thus it is enough for a Pentecostal church to have public visibility for it to attract worshippers.

The CRMI does not operate is a similar milieu in the USA. In the USA, churches must compete aggressively to win followers and to keep them. Thus to succeed as an American church, the CRMI must make a conscious effort not only to win worshippers, but also to keep them. It must compete with other religious institutions and it must adopt an aggressive missionary strategy. The CRMI is not alone in this respect. Many local African Charismatic traditions realize after they have extended their influences to the West that they need to be more aggressive in recruiting followers than they were at home, if they are to survive. Since its beginning, the CRMI has developed different kinds of approaches to win people to it. According to Rev. Eyim-Danquah, although they 
constantly pray for increase in the church's membership, it became incumbent upon the few pioneers who started the CRMI to devise practical methods for bringing people to the church. Ghanaians living in Miami became the first point of contact. These Ghanaians started going to the church and inviting other Ghanaians they knew, as well as people of other African nationalities and their friends of Western descent. Rev. Eyim-Danquah stated that they also used both print and electronic media for inviting people. While the print media, such as flyers, postcards and hand bills were distributed at public spaces, including train and bus stations, the electronic media, such as the church's website, facebook, and voice messages were also used to advertise the church and to invite people to special programs organized by the church. The Church is also engaged in one-on-one witnessing to people at public spaces, such as colleges and around the vicinity of supermarkets. This kind of direct proselytizing is not typical of Pentecostal churches in Ghana. It is a North American tradition the CRMI felt it had to adopt if it were to survive in South Florida.

According to Mr. Dodjis, one of my respondents, the one-on-one recruitment method, entails directly contacting people the Church’s missionaries come across, sharing with them the Christian message on salvation and inviting them to accept Jesus Christ as their Lord and personal Savior. They that due to the unsuccessful nature of this method, they used it for only twice and never employed it at the group level anymore. However, individual worshippers are frequently encouraged to spread the gospel to their friends and people they meet at their work places, and in their neighborhoods, and to invite them to the Church's programs. According to most members I interviewed, the one-on-one recruitment seem to be one of the most effective tools for their evangelism, as it leads to 
winning many people over to the church. About twenty out of twenty-five members interviewed on this issue affirmed that they became members of the church upon the invitation of another member.

One very essential element I discovered about recruitment and evangelism in the church is the phenomenon of giving testimonies. These are practices incorporated into the church's routine activities whereby members are invited to recount what God has done or is doing for them since they "accepted Christ" by becoming members of the CRMI. During my participation in church programs I observed that at the end of every church service, the pastor throws open invitation for testimonies. I realized at each occasion, one person or two came out to tell what they considered to be miraculous healings and other successes they experienced as a result of their participation in religious activities of the church or after they had been prayed for by the pastor. A case in point was the healing experience of one Madam Xoese. The woman was prayed for after she was diagnosed with a bad heart condition. She needed a heart transplant. The woman later came back and testified about how, after she had been prayed for, she went back for review and the doctor's report showed that her heart was in good condition. She did not require the transplant anymore. This woman's story and other similar incidences have become a great source of attraction to the church and a crucial retention tool. As a sign of the Church's healing abilities, she has singlehandedly brought in more new members than any other member in the Church. The pastor also capitalizes on these phenomena of miraculous healings to remind congregants to always make efforts to bring somebody to church with them at each of their visits. 
In spite of these innovations and adaptations intended to make the CRMI a good fit for many South Floridian Christians, it still has a leadership pattern can be described as traditionally Ghanaian. Power is centrally controlled by the family of the Rev. Dr. Eyim-Danquah. He is the head of the Church and his wife is the deputy. His children are in charge of all key portions of the CRMI's tradition, making the Church seem like a family-run business or an indigenous religious shrine in Ghana. The CRMI lacks the bureaucratic organizational pattern typical of both Ghanaian and American Pentecostal tradition. As I have indicated, this pattern in CRMI has a history. It originated as a pragmatic response to the root causes of the schism than occasioned the re-organization of the worshipping cell and inaugurated the American or international mission agenda of the CRMI. A way to ensure that there would be no mutiny with church's leadership was to keep all leadership within the family. While rooted, perhaps, in Ghanaian religious tradition, it is also a part of CRMI's innovative tradition. The leaders maintain some Ghanaian cultural elements, de-emphasize others, adopt elements from American culture and create totally new practices as they see fit.

\section{Conclusion}

The Christian Restoration Ministries International has a tradition that can best be captured by the concept of invented traditions. People invent tradition when they seek a symbolic link with the past. Others invent traditions when old practices need to be changed because they become redundant in the face of new realities. This latter reason explains largely the nature of CRMI's practices. Originating as a Ghanaian worshipping

cell, the CRMI had to open its doors to other African and non-African elements after a 
schism. Some of its original Ghanaian features would not work in the face of members coming from different cultural backgrounds. Many of these are Americans. To accommodate the needs of its new community of worshippers the Church introduced innovations modelled largely on traditional American Charismatic or Christian practices. Yet the Church as not lost all of its Ghanaianness. The point of the chapter's discussion is that because the CRMI tradition is practiced in South Florida, which is a context in which it has been influenced by other, that is, American forms of religious practice, or where conditions of life have compelled the practitioners to modify their practices, it is difficult to discern the usual frame of reference in a Ghanaian Pentecostal worship tradition. 


\section{CHAPTER FIVE \\ CONCLUSION OF THESIS}

This final chapter highlights the premise on which this thesis has been established: that the central roles of ordinary immigrants in the rooting of African Pentecostal church in the West, as a case of reverse mission process, appears to have received little scholarly attention. It also provides a summary of the main findings and emerging trends in contemporary African Pentecostal Christian enterprises as aspects of reverse mission process in the history in Christianity.

\section{Premise of the Thesis}

The rise of African Christian communities in the West has been viewed from different scholarly perspectives leading to different conclusions. Some scholars of mission studies have concluded that the twenty-first century Christian missionary enterprise is experiencing a significant shift from the Western worlds (the former heartland of Christianity) to Africa and other Third world continents (previous recipients of the gospel from Western missionaries). ${ }^{121}$ In Africa, the Pentecostal and Charismatic churches have been identified as the precursors in this Christian enterprise who continue to make a significant impact on the Christian religious landscape of the West. Consequently, most researchers in Christian mission studies have conclusively described the contemporary

${ }^{121}$ J. K. Asamoah-Gyadu, "An African Pentecostal in Eastern Europe: The Church of the 'Embassy of God’ in Ukraine,” Pneuma: The Journal of the Society for Pentecostal Studies 27 (2005), 297. 
flow of Christian religious currents from Africa to the West as "remissionization," "reverse mission," or mission in reverse. ${ }^{122}$

This Christian religious shift is a process within which individuals and churches are rooting the African Pentecostal ethos in the West. I have observed that in their sweeping generalizations on the reverse mission phenomenon, the role of ordinary or lay immigrants who form the substratum for initiating, planting and leading these churches is usually ignored by researchers. This creates the impression that the emerging African Christian mission enterprise in the West is always an exclusive product of the conscious efforts of established churches African to evangelize the Western worlds. The objective of this project was to uncover the role of lay migrants in the rooting of African Pentecostal traditions in America.

\section{Summary of Findings}

Using the Christian Restoration Ministries International, a Ghanaian founded charismatic church in South Florida as a case, this investigation into the lay immigrants' role in the rooting of African Pentecostalism in America used an ethnographic approach. Like most existing African Pentecostal churches in West, the CRMI originated from the private religious initiatives (home prayer cell) of some Ghanaian immigrants who came to America to better their living conditions. Convinced that religious practice was crucial to the success of their migration to the USA, the Ghanaian migrants carried their Ghanaian Christian religious beliefs and practices to South Florida, this shows that migration is a

\footnotetext{
${ }^{122}$ Asamoah-Gyadu, “An African Pentecostal in Eastern Europe”, 297. See also Israel Olofinjana, "Reverse Missions: The Emergence of African Churches in Britain," Orita: Ibadan Journal of Religious Studies XLV. 1 \&2 (June \& December, 2013), 133-154. See also, Ogbu Kalu, African Pentecostalism: An Introduction (New York: Oxford University Press, 2008), 271-272.
} 
channel through which forms of African Pentecostal expressions are transferred to the West. This study about the rise of an African Pentecostal and Charismatic Church in South Florida confirms Afe Adogame's view that the religions' mobility is a product of humans' mobility. ${ }^{123}$ Thus as people continue to migrate, their religious traditions and expressions will as well migrate with them.

My study has found that context is another crucial factor for the rise of African Pentecostal Christianity in the USA. The religious, socio-cultural, economic and political settings within which Ghanaian immigrants find themselves upon arrival in the USA significantly influence their use of religious rituals and narratives. Migration related challenges of the Ghanaian immigrants in the USA push them to perpetuate their Ghanaian Christian spiritualties in the USA. My study has also found out that many migrants from Ghana view American churches and their approaches to be inadequate in meeting their spiritual needs. In the case of the CRMI, this situation precipitated the initiation of the migrants own religious cell. This cell would later develop into a Charismatic church. This development demonstrates the agency of migrants in the rooting of Ghanaian Pentecostalism in the USA. It can also be said that the ethos of life in the American setting and immigrants' experiences of African Pentecostal spirituality informed their religious agency.

Because Ghanaian immigrants were influential in the planting of the CRMI South Florida, the tradition has a strong African Pentecostal foundation. Thus, the influence of African religious worldview is pervasive in the tradition of CRMI. One can see these in

${ }^{123}$ Adogame, “Towards Christian Disneyland” in Kane and. Leedy (eds.), African Migrations, 175. 
many of the Church's activities and how the worshippers respond to their life situations. African spirituality remained deeply rooted to the core of every church activity. In all, the church found it necessary to adapt to the American socio-cultural and economic context, through the making of a number of innovations.

These innovations were deemed necessary for the Church to root itself successfully as a Ghanaian-founded church in Miami. These innovations have, however, made the church appears as neither typical Ghanaian Pentecostal tradition, nor typical American Pentecostal church. In other words, the church appears to be partly Ghanaian and partly American. This explains my conclusion that the tradition is invented. I must mention, however, that it is this very element of inventiveness that enables the global Pentecostal traditions to travel anywhere and root themselves as demonstrated in the case of Christian Restoration Ministries International in South Florida. 


\section{BIBLIOGRAPHY}

\section{Books}

Adogame, Afe, African Christian Diaspora: New Currents and Emerging Trends in World Christianity (New York: Bloomsbury, 2013).

Adogame, Afe, Gerloff, Roswith and Hock, Klaus, Christianity in Africa and the African Diaspora: The Appropriation of a Scattered Heritage, (New York: Continuum International Publishing Group, 2008).

Akinade, Akintunde E., "Non-Western Christianity in Non-Western World: African Immigrant Churches in the Diaspora”, In Jacob K. Olupuna and Regina Gemignani (eds.), African Migrant Religion in America (New York University Press, 2007).

Anderson, Allan, An Introduction to Pentecostalism: Global Charismatic Christianity (Cambridge: Cambridge University Press, 2004).

To the Ends of the Earth: Pentecostalism and the Transformation of World Christianity (Oxford University Press, 2013).

, "Varieties, Taxonomies and Definitions" in Allan Anderson, Michael Bergunder, Andre Droogers, Cornelis Van Der Laan (eds.) Studying Global Pentecostalism: Theories and Methods, (Berkeley: University of California Press, 2010).

Archer, Margaret S., Culture and Agency: The Place of Culture in Social Theory (New York: Cambridge University Press, 1988).

Asamoah-Gyadu Kwabena J., African Charismatics: Current Developments within Independent Indigenous Pentecostalism in Ghana (Leiden: Koninklijke Brill NV, 2005).

Baeta, C. G., Prophetism in Ghana: A Study of Some 'Spiritual' Churches (London: SCM Press Ltd, 1962).

Meyer, Birgit, Translating the Devil: Religion and Modernity among Ewe in Ghana (Trenton-NJ: African World Press, Inc., 1999).

Dahlin, Olav, Zvinorwadza: Being a Patient in the Religious and Medical Plurality of the Mberengwa District, Zimbabwe (Frankfurt am Main: Peter Lang, 2002). 
Daniels, David D., 'African Migrant Churches in the United State and the study of Black Church History' in Olupuna and Regina Gemignani (eds.), African Migrant Religion in America (New York University Press, 2007).

Eliade, Mircea, 'Reality of the Sacred' in Daniel L. Pals, Eight Theories of Religion (New York: Oxford University Press, 2006).

Geertz, Clifford, “Thick Description: Toward an Interpretive Theory of Culture”, in The Interpretation of Cultures: Selected Essays (New York: Basic Books, 1973).

Gifford, Paul, African Christianity: Its Public Role (Bloomington: Indiana University Press, 1998).

Hammersley, Martyn and Atkinson, Paul, Ethnography Principles in practice (Third edition) (New York: Routledge Taylor \& Francis Group, 2007).

Hammersley, Martyn, What is Qualitative Research? (New York: Bloomsbury Publishing Plc, 2013).

Harfst, Ursula, "The 'Program for Cooperation between German and Foreign Language Churches' and African Churches in the Rhein-Ruhr-Region: Developments from 1999" in Afe Adogame, Roswith Gerloff and Klaus Hock (eds.) Christianity in Africa and the African Diaspora: The Appropriation of a Scattered Heritage (New York: Continuum International Publishing Group, 2008).

Hobsbawm, Eric, "Introduction: Inventing Traditions" in Eric Hobsbawm and Terence Ranger (Eds.) The Invention of Tradition (Cambridge: Cambridge University Press, 1983).

Hock, Klaus, "Religion on the Move: Transcultural Perspectives. Discourses on Diaspora Religion between Category Formation and the Quest for Religious Identity" in Adogame et.al., (ed.) Christianity in Africa and the African Diaspora the Appropriation of a Scattered Heritage (New York: Continuum International Publishing Group, 2008).

Hollenweger, W. J., Allan Anderson, An Introduction to Pentecostalism: Global Charismatic Christianity (Cambridge: Cambridge University Press, 2004).

Jenkins, Philip, The Next Christendom: The Coming of Global Christianity (New York: Oxford University Press, 2002).

Kalu, Ogbu, African Pentecostalism: An Introduction (New York: Oxford University Press, 2008). 
Kim, Sebastian C. H., "The Future Shape of Christianity from an Asian Perspective” in Frans Wijsen and Robert Schreiter (eds) Global Christianity: Contested Claims (New York: Rodopi B.V., Amsterdam, 2007).

Laan, Cornelis Van Der, “Historical Approach” In Allan Anderson, Michael Bergunder, Andre Droogers, Cornelis Van Der Laan (eds) Studying Global Pentecostalism: Theories and Methods, (Berkeley: University of California Press).

Maane, J. V., Tales of the field: On Writing Ethnography, (Chicago: University of Chicago Press, 1988).

Mahmood, Saba, Politics of Piety: The Islamic Revival and the Feminist Subject (Princeton: Princeton University Press, 2005).

Maxwell, David, African Gifts of the Spirit: Pentecostalism \& the Rise of a Zimbabwean Transnational Movement (Harare: Weaver Press, 2006).

Meyer, Birgit, "Pentecostalism and Globalisation" in Allan Anderson, Michael Bergunder, Andre Droogers, Cornelis Van Der Laan (Eds.) Studying Global Pentecostalism: Theories and Methods, (Berkeley: University of California Press, 2010).

Muganbi, J. N. K., African Heritage and Contemporary Christianity (Nairobi: Longman Kenya Ltd., 1989).

Ojo, Matthews A., "Transnational Religious Networks and Indigenous Pentecostal Missionary Enterprises in the West African Coastal Region” in Afe Adogame, Roswith Gerloff and Klaus Hock (Ed.) Christianity in Africa and the African Diaspora: The Appropriation of a Scattered Heritage (New York: Continuum International Publishing Group, 2008).

Olupuna, Jacob K. and Gemignani, Regina (eds), African Migrant Religion in America (New York University Press, 2007).

Omenyo, Cephas N., Man of God Prophesy Unto Me: The Prophetic Phenomenon in African Christianity (Edinburgh University Press, 2011).

Pals, Daniel L., Seven Theories of Religion (New York: Oxford University Press, 2006).

Ranger, Terence, "The Invention of Tradition in Colonial Africa” in Eric Hobsbawm and Terence Ranger (Eds.) The Invention of Tradition (Cambridge: Cambridge University Press, 1983). 
Robins, Joel, “Anthropology of Religion” in Allan Anderson, Michael Bergunder, Andre Droogers, Cornelis Van Der Laan (eds) Studying Global Pentecostalism: Theories and Methods, (Berkeley: University of California Press, 2010).

Sanneh, Lamin, "Introducing the Oxford Series", in Anders Heaton Anderson, To the Ends of the Earth: Pentecostalism and the Transformation of World Christianity (Oxford University Press, 2013).

Truzzi, M. (ed.), Verstehen: Subjective Understanding in the Social Sciences, Reading (MA: Addison-Wesley, 1974).

Walls, Andrew, "The gospel as liberator and prisoner of culture" In The missionary movement in Christian History (London: T\&T Clarke, 2004).

Warrington, Keith, Pentecostal Theology: A Theology of Encounter (New York: T\&T Clark, 2008).

\section{Journal Articles}

Anderson, Allan H., "Types and Butterflies: African Initiated Churches and European Typologies”, International Bulletin of Missionary Research (July, 2001).

Asamoah-Gyadu, J. K., "An African Pentecostal in Eastern Europe: The Church of the 'Embassy of God' in Ukraine", Pneuma: The Journal of the Society for Pentecostal Studies, 27 (2005).

Dovlo Elom, “African Culture and Emergent Church forms in Ghana” Exchange: Journal of Missiological and Ecumenical Research, 33 (2004).

, "Comparative Overview of Independent Churches and Charismatic Ministries in Ghana”, Trinity Journal of Church History and Theology, Vol. 2 (December, 1992).

Mabogunje, A. L., “System Approach to Rural-Urban Migration” Geographical Analysis 2 (1970).

Olofinjana, Israel, "Reverse Missions: The Emergence of African Churches in Britain,” Orita: Ibadan Journal of Religious Studies XLV. 1 \&2 (June \& December, 2013).

Omenyo, Cephas N., "Man of God Prophesy Unto Me: The Prophetic Phenomenon in African Christianity" Studies in World Christianity. Volume 17, Page (2011). 
Portes, Alejandro, "Towards a New World: The Origins and Effects of Transnational Activities,” Ethnic and Racial Studies, 22.2(1999).

Shapiro, Susan P., “Agency Theory”, Annual Review of Sociology, Vol. 31 (2005). ter Haar, Gerrie, "Strangers in the Promised Land: African Christians in Europe," Exchange, 24 (Feb. 1995).

Turner, H. W., “A Typology of African Religious Movements,” Journal of Religion in Africa 1 (1967).

Waker, Grant, 'Are the Golden Oldie Still Worth Playing? Reflection on History Writing among Early Pentecostals,' Pneuma 8:2 (1986).

Wildemuth, B. M., “Understanding and Evaluating Qualitative Research”, Journal of Marriage and the Family' 63 (1995).

\section{Internet Source}

Anfara, Vincent A., et al. "Qualitative Analysis on Stage: Making the Research Process More Public,” http://www.researchgate.net/publication/228779917, Accessed August 5, 2015.

Christine P. Gambino, Edward N. Trevelyan, and John Thomas Fitzwater, “The ForeignBorn Population From Africa: 2008-2012”, http://www.census.gov/content/dam/Census/library/publications/2014/acs/acsbr12 -16.pdf , Issued October 2014, Accessed, September 25, 2015.

Eyim-Danquah, Emmanuel, "History of the Christian Restoration Ministries International” www.CRMIus.org, Accessed, November 20, 2015. 